IZA DP No. 8677

Individual Perceptions of Local Crime Risk

Martin Salm

Ben Vollaard

November 2014

Forschungsinstitut zur Zukunft der Arbeit Institute for the Study of Labor 


\title{
Individual Perceptions of Local Crime Risk
}

\author{
Martin Salm \\ CentER, Tilburg University \\ and IZA \\ Ben Vollaard \\ CentER and TILEC, Tilburg University
}

\section{Discussion Paper No. 8677 \\ November 2014}

\author{
IZA \\ P.O. Box 7240 \\ 53072 Bonn \\ Germany \\ Phone: +49-228-3894-0 \\ Fax: +49-228-3894-180 \\ E-mail: iza@iza.org
}

Any opinions expressed here are those of the author(s) and not those of IZA. Research published in this series may include views on policy, but the institute itself takes no institutional policy positions. The IZA research network is committed to the IZA Guiding Principles of Research Integrity.

The Institute for the Study of Labor (IZA) in Bonn is a local and virtual international research center and a place of communication between science, politics and business. IZA is an independent nonprofit organization supported by Deutsche Post Foundation. The center is associated with the University of Bonn and offers a stimulating research environment through its international network, workshops and conferences, data service, project support, research visits and doctoral program. IZA engages in (i) original and internationally competitive research in all fields of labor economics, (ii) development of policy concepts, and (iii) dissemination of research results and concepts to the interested public.

IZA Discussion Papers often represent preliminary work and are circulated to encourage discussion. Citation of such a paper should account for its provisional character. A revised version may be available directly from the author. 
IZA Discussion Paper No. 8677

November 2014

\section{ABSTRACT}

\section{Individual Perceptions of Local Crime Risk}

We provide evidence that perceptions of crime risk are severely biased for many years after a move to a new neighborhood. Based on four successive waves of a large crime survey, matched with administrative records on household relocations, we find that the longer an individual lives in a neighborhood, the higher their perception of the crime rate in the neighborhood. This finding holds irrespective of whether the move is from a relatively lowcrime to a relatively high-crime area or vice versa. We find that avoidance behavior adjusts in line with the observed changes in beliefs.

JEL Classification: D81, K42

Keywords: heuristic, victimization, crime

Corresponding author:

Martin Salm

Tilburg University

P.O. Box 90153

5000 LE Tilburg

The Netherlands

E-mail:m.salm@tilburguniversity.edu

\footnotetext{
* The authors thank Padmaja Ayyagari, Andrew Caplin, Philip Cook, Glenn Harrison, Jan Kabatek, Tobias Klein, Emily Owens, Arthur van Soest and Elke Weber for valuable comments and suggestions as well as participants of the 5th Transatlantic Workshop on the Economics of Crime in Frankfurt (2013), the UCL-NHH Crime Workshop in London (2013), the Health Economics Conference in Grindelwald (2014), the 6th Annual Meeting on the Economics of Risky Behaviors in Medellin (2014), the International Symposium on Environmental Criminology and Crime Analysis in Kerkrade (2014), and seminar participants at Aarhus University, CPB, Erasmus University Rotterdam, Essen University, Ruhr University Bochum and Tilburg University. The provision of individual-level survey and administrative data by Netherlands Statistics is gratefully acknowledged.
} 


\section{Introduction}

Crime is not only a story of upbringings gone wrong or school careers that ended nowhere, but also of the environment in which potential offenders currently operate, and of the actions and reactions of potential victims in particular. Deliberately or inadvertently, potential victims expand and also limit the set of criminal opportunities that are available to offenders (Cohen and Felson 1979; Cook 1986). Victim behavior features prominently in studies of how offenders select tactics and targets (Bernasco, Block and Ruiter 2013). Even relatively simple and cheap precautionary measures have been shown to greatly affect offenders' choices (Vollaard and Van Ours 2011; Van Ours and Vollaard forthcoming).

Taking appropriate precautions is not straightforward, however. Potential victims face several unknowns when deciding how to allocate their scarce resources towards crime prevention. One of the unknowns is the crime risk to which they are actually exposed. ${ }^{1}$ It is challenging to deduce something about the nature of this risk from the - often prolific - descriptions of crime, since those descriptions may not apply to the individual's own situation. The danger from crime varies greatly between places, individuals and time of day. ${ }^{2}$ Direct observation of criminal events tends to be rare, rendering it another poor source of information about the risk. Without a clear idea of the risk, deciding which precautionary measures to take becomes difficult. Uncertainty about the outcomes of alternative actions is common in many domains of life, but it may be particularly costly within the context of crime. Think about having to experience a robbery first before taking proper precautions. Learning from experience is also difficult because crime events tend to be rare. For instance, on average a US household experiences burglary once every 50 years (Lauritsen and Rezey 2013) and a Dutch household once every 40 years (IVM 2011).

How potential victims learn about the crime risk has been largely ignored in the study of crime. If potential victims' actions play a role at all, as in Ehrlich's $(1981,1996)$ model of the market for offenses, then their behavior has been modeled under the assumption that all information relevant for making the right decision is known. ${ }^{3}$ Potential victims are assumed to be able to

\footnotetext{
${ }^{1}$ Another unknown is the effectiveness of precautionary measures. Victim precaution has the characteristic of a credence good. Simply put: burglars do not leave a note when they pass a home because it is too well-protected, leaving the home owner uncertain about the value of precautionary measures that she has taken.

${ }^{2}$ See Weisburd et al. (2012) on risky places, Cohen and Felson (1979) on individual risk, Felson and Poulsen (2003) on risk at different times of the day.

${ }^{3}$ Even though crime is a risk to which everybody is exposed, crime preventive behavior has seen little study (Cook and MacDonald 2011). Economists took some interest in crime preventive behavior in the late 1970s and the early 1980s (Clotfelter 1977; Ehrlich 1981; Cook 1986). This work resulted in models in which the crime rate was determined by the simultaneous actions of both offenders and victims. This line of research was largely
} 
act in anticipation of the crime risk. They invest in crime precaution up to the point where the marginal costs of prevention are equal to the marginal benefits. In these static models, the crime rate is determined by a one shot interaction between potential offenders and potential victims. In contrast, if potential victims do not have a perfect understanding of the crime risk, then their level of precaution may well be off. As a consequence, the crime rate resulting from the interaction between imperfectly informed potential victims and offenders may be very different from the one in models with well-informed agents. This is of great relevance to our understanding of what drives crime and also of policies to address crime, because it suggests another cause of crime: mistakes made by potential victims due to distorted perceptions of the crime risk. These mistakes may result in inadvertent rather than deliberate exposure to the crime risk. Our aim is to uncover whether people's beliefs about the crime risk are off, and if so, whether the bias is large and long-lasting, and how it can be explained.

We develop a test that unambiguously shows whether perceptions of local crime risk are biased or not, based on a method not previously used in the literature about perception of risk. We take a risk that is shared by a group of individuals, the crime risk in the neighborhood in which they live, and study how perceptions of this risk change with the time since their move into the neighborhood. If the crime risk in the new neighborhood is stable, then in the absence of any systematic bias, on average beliefs about crime should not change with time since the move date. If risk perceptions of individuals systematically increase or decrease with increasing time since the move date, then the perceptions must be off at some point in time. Our test relies on changes in crime risk perceptions over time rather than a comparison of objective crime rates with elicited subjective probabilities or assessments of the number of crimes within a population, as in Slovic (1987) and later Dominitz and Manski (1997) and Quillian and Pager (2010). Our approach has the advantage that it does not rely on the assumption that people are able to express their beliefs about crime risk in terms of percentage chances (see Krumpal et al. 2011 for a discussion). For our test, verbal assessments of likelihood suffice. Our dynamic perspective also reveals useful information about the way people learn about crime risk. An

discontinued, except for empirical work into the use of guns as a private deterrent (for instance, Cook and Ludwig 2006; Acquisti and Tucker 2011) and car security (Ayres and Levitt 1998; Gonzalez-Navarro 2013; Van Ours and Vollaard forthcoming). Other work is focused on externalities emanating from precautionary measures, including Shavell (1991), Hui-Wen and Png (1994), Helsley and Strange (1999, 2005), Di Tella, Galiani and Schargrodsky (2010) and Amodio (2013). Within criminology, there is an extensive literature on fear of crime and its measurement, which is primarily focused on fear as an outcome rather than as an input into crime preventive behavior (for an exception see Jackson and Gray 2010). Similar to economics, the interest in precautionary behavior in criminology waxed in the 1970s and 1980s (e.g. Skogan and Maxfield 1981) and waned afterwards, with Van Dijk (1994) as a rare exception. This also holds for work by psychologists in this area (e.g. Tyler 1980). 
advantage of our focus on the population base rate rather than personal risk is that it allows us to abstract from the complex interaction between crime risk perceptions and individual precautions. $^{4}$

Our empirical approach is based on following cohorts of movers, and we examine how their perception of crime risk in their neighborhood changes with increasing time since their move date. In our estimation, we control for cohort fixed-effects for annual cohorts of movers and for underlying time trends at the neighborhood level based on the assumption that time trends in crime are the same for incumbent residents and different cohorts of movers. We also control for selective attrition by excluding future movers from our sample. Our empirical strategy is similar to Borjas (1995), who examines how immigrant wages evolve with time since immigration - based on the assumption that underlying time trends are the same for immigrant and native wages.

We use micro-level data from the Netherlands Crime Survey (IVM), a cross-sectional survey that is repeated annually. It is one of the largest crime surveys in the world relative to size of population. We merge four recent waves of the survey (2008-2011), providing us with a sample of about half a million respondents, one out of 25 of the Dutch population aged 15 or over. Uniquely, we are able to match the survey data with administrative records on household moves which includes all places of residence of respondents for the period between 1995 and 2011. We show the elicited beliefs about crime risk to have face validity: the perceived prevalence of a crime is strongly related to its rate of occurrence.

We find that with increasing time since the move date, residents perceive the crime risk in their neighborhood to be higher, closer to the beliefs of the incumbent residents. Changes in risk perceptions are large and statistically significant. The adjustment of beliefs after moving to a new neighborhood is exceedingly slow. The adjustment process can take 10 years or longer. Strikingly, the upwards adjustment in risk perceptions holds irrespective of whether the move is from a relatively low-crime to a relatively high-crime area or vice versa. Hence, after the initial adjustment at the time of move, perceptions of the neighborhood crime risk are always lower shortly after the move than they are longer after the move. Our assertion that the survey questions reveal the beliefs that respondents truly hold is validated by the finding that changes in elicited beliefs with time since the move date are in line with changes in avoidance behavior.

\footnotetext{
${ }^{4}$ When asked about personal risk, it is unclear to what extent respondents take into account the mitigating impact of precautionary measures; such concerns are absent for perceptions of neighborhood crime risk. In addition, we do not know how personal risk evolves over time, whereas we do know how the neighborhood crime risk changes.
} 
In other words, we not only find particular patterns in the beliefs that people report in the survey, but also that people act on those beliefs.

Our results suggest the presence of a judgmental bias. One explanation for our findings is that people follow the so-called availability heuristic when forming beliefs of the local crime risk. When using the availability heuristic, the probability of an event is judged by the ease with which instances can be brought to mind (Tversky and Kahneman 1973). People who just moved into a neighborhood have few first-hand or second-hand experiences with crime in that locality. When asked about the local crime risk, relatively few instances can be brought to mind. Over time, the stock of crime-related events in the new locality an individual draws upon goes up, resulting in a progressively greater perceived risk of crime. ${ }^{5}$ Thus the longer people live in a neighborhood, the greater the perceived crime risk. We also observe far less adjustment in risk perceptions for moves within a neighborhood than for moves outside a neighborhood. That fits with the availability heuristic, with the stock of experiences built up in the previous place of residence being partly relevant for nearby moves but not for moves further away.

An alternative and observationally equivalent explanation for our findings is the so-called choice-supportive bias or cognitive dissonance (Akerlof and Dickens 1982). People may feel inclined to justify their decision to move house by casting characteristics of their new living environment in too positive a light. The upward adjustment in risk perception with increasing time since the move date can then be explained by a diminishing tendency to distort characteristics of their environment.

Our paper contributes to the crime literature by showing that potential victims' perceptions of crime risk can be off substantially and for a long time. So far, the study of the beliefs of actors in the model of crime is largely limited to offenders (some recent studies include Lochner 2007, Hjalmarsson 2009 and Loughran et al. 2014). We show that judgment of crime risk is not static, but evolves after a change in environment. As such, we offer new insight into how crime risk perceptions evolve over time and how these changes can be explained, compared to static comparisons of the level of objective and subjective probabilities (Dominitz and Manski 1997; Quillian and Pager 2010). The judgmental bias of potential victims that we find may well have consequences for precautions that they take, as our results for avoidance behavior show.

\footnotetext{
5 This interpretation also fits well with results from evolutionary biology: bad events have longer lasting and more intense consequences for impression formation than good events (Baumeister et al. 2001: 344-348). From this perspective, it makes sense that stories about crime in the neighborhood and an individual's own experience of crime have a much larger effect on the formation of beliefs about the neighborhood crime risk than the realization that crime did not happen or only rarely.
} 
Potential victims may not make the right preventive decisions simply because they do not have the necessary information. This also suggests an alternative way of addressing crime: targeting the behavior of potential victims. If government intervention is able to affect the level of crime prevention, for instance by mandating burglar-resistant features in residential construction or anti-theft devices in cars (Vollaard and Van Ours 2011; Van Ours and Vollaard forthcoming), then this helps people to avoid large losses suffered during the time that it takes to gather better information about the crime risk. In other words, we provide an alternative argument for government intervention in preventive behavior, next to the externalities emanating from private victim precaution.

Our paper also contributes to the literature on risky choice. We present rare empirical evidence on the evolution of beliefs about the population base rate of a risky event in a natural setting. Our paper is related to work in the context of health preventive behavior and natural hazard mitigation, two other domains where the formation of beliefs is of great relevance to individual wellbeing. In line with our results, Gallagher (2014) finds that people deal with flood risk as if they use the availability heuristic when updating their beliefs. Recent experiences with a flood are found to be the primary driver of current beliefs. Similarly, within the health context, Smith et al. (2001) find that smokers often quit only after a smoking-related health condition was diagnosed. We add to this strand of the literature by studying how people play against another human being rather than nature. People have been shown to deal with risk differently when the threat is posed by a stranger with bad intentions (Slovic et al. 1987).

The remainder of the paper is structured as follows. The next section presents a model of learning about risk. Section 3 discusses the empirical strategy. Section 4 describes the data. In Section 5, we present the estimation results. In Section 6, we discuss our findings and draw conclusions.

\section{Learning about crime risk}

Individuals learn about the risk of crime in their neighborhood in many ways, including their own experiences, observation of criminal events, and description of the experiences of others such as coverage in local news media and stories from friends and neighbors. When individuals move into a new neighborhood, they form an initial assessment of crime risks. Over time, individuals adjust their perceptions of crime risk as they obtain new information.

We can think of learning about the risk of crime in a new neighborhood as a process of Bayesian updating. At the time of moving, individuals form a prior distribution about the crime risk in 
the new place of residence. We assume that this prior distribution is a normal distribution with mean $\mu_{p}$ and variance $\sigma_{p}^{2}$. Later in this section, we discuss alternative theories of how individuals form priors about the risk of crime in a new environment. At this point, it suffices to state that the mean of the prior distribution is not necessarily equal to the true level of crime risk in the neighborhood, which we define as $\theta$.

After moving to a new neighborhood, individuals gradually obtain new information about the level of crime risk in the new environment. We assume that in every period $t=1 \ldots T$ after the move, individuals receive a signal about the level of crime risk. For example, being victimized can form a high signal for that period. We denote the signal as $X_{t}$, and we assume that it is normally distributed with mean $\mu_{t}$ and variance $\sigma_{0}^{2}$. If $\mu_{t}=\theta$ then the mean of the signals reflects the true level of crime risk. We assume that individuals know the variance of the signal, but they do not know the mean of the distribution. We further assume that signals are independently distributed across periods.

Individuals update their prior beliefs about the risk of crime based on the signals they have received to date. At the end of period $t$, individuals have received signals $X_{1}, \ldots, X_{t}$. We denote the average value of these signals as $\bar{x}_{t}$. Posterior beliefs about $\theta$ at the end of period $t$ are normally distributed with probability density function $f_{t}(\theta)$. The mean value $\mu_{t}$ of the posterior distribution is given by the formula below (for a derivation see Wonnacott and Wonnacott, 1985: 599, Theorem 19-23):

$$
\mu_{t}=\frac{t \sigma_{0}^{2}}{t \sigma_{0}^{2}+\sigma_{p}^{2}} \bar{x}_{t}+\frac{\sigma_{p}^{2}}{t \sigma_{0}^{2}+\sigma_{p}^{2}} \mu_{p}
$$

This formula implies that with increasing time since the move date, beliefs about crime risks depend more on the average value of the signals $\bar{x}_{t}$ and less on the mean of the prior distribution $\mu_{p}$. For the case $\mu_{p}<\mu_{t}$, individuals' beliefs about crime risk are likely to increase with time since the move date. For the case $\mu_{p}>\mu_{t}$, individuals' beliefs about crime risk are likely to decrease with time since the move date.

In the following, we discuss theories of how $\mu_{p}$ and $\mu_{t}$ are formed. Standard models of victim behavior assume that individuals have rational expectations (Ehrlich 1981, 1996). Under rational expectations, both the mean of the prior distribution $\mu_{p}$ and the mean of the signals $\mu_{t}$ should not systematically deviate from the true level of crime risk $\theta$. In other words, under rational expectations, if the crime risk is constant, then perceptions of the crime risk should not 
systematically change with time since the move date. Formally, if $\mu_{p}=\theta$ and $\mu_{t}=\theta$, then it is not possible that $\mu_{p} \neq \mu_{t}$.

The behavioral economics and psychology literature provides theories for why beliefs may deviate from rational expectations, i.e. why risk perceptions on average may change with time since the move date. Some biases are the effect of information-processing rules, called heuristics, which help to simplify decision making (Slovic et al. 1987: 281). Biases in judgment can also result from motivation, such as when beliefs are distorted by wishful thinking. Below, we discuss several biases that may be relevant to our context.

The perceived crime risk is likely to go up with time since the move date if people follow the availability heuristic. The availability heuristic posits that individuals judge an event to be likely or frequent if instances of the event are easy to imagine or recall (Tversky and Kahneman 1973). People who have just moved into a neighborhood have few first-hand or second-hand experiences with crime in that locality. When asked about the local crime risk, relatively few instances can be brought to mind. Over time, the stock of crime-related events in the new locality an individual draws upon goes up, resulting in a progressively greater perceived risk of crime.

The perceived neighborhood crime risk may go up with time since the move date for other reasons as well. If beliefs are affected by choice-supportive bias or cognitive dissonance (Akerlof and Dickens 1982), then a similar pattern emerges. People may feel inclined to justify their decision to move house by viewing it in too positive a light. This bias could lead to an overly optimistic assessment of the crime risk in the period after a move. It is difficult to say how long people may feel a tendency to justify their move, but this tendency is likely to diminish with time. In this case, an upwards adjustment in beliefs is due to a diminishing tendency to be overly optimistic rather than to obtaining new information, as in the availability heuristic discussed above.

The perceived risk is also likely to be adjusted upwards if individuals with over-optimistic beliefs about the neighborhood crime risk are overrepresented among movers to that neighborhood - similar to the winner's curse in auctions. Over time, these movers come to realize that they had too positive a picture of the neighborhood they moved to. The initial misperception and following adjustment result in a positive relation between time since the move date and perceived risk. 
Finally, an upwards adjustment in beliefs after a move can also hold if people follow the anchoring and adjustment heuristic (Tversky and Kahneman 1974) - but only if the move is to a neighborhood with a crime risk that is higher than in the previous neighborhood of residence. The anchoring and adjustment heuristic posits that an individual's prior beliefs are determined by an anchor, e.g. the level of crime in their previous neighborhood. Translated to our context, this implies that individuals who move to a neighborhood with a crime risk that is higher than in the previous neighborhood of residence are likely to initially underestimate the crime risk in the new neighborhood. This theory can be distinguished from the previous ones since the adjustment of beliefs should be exactly opposite for those who moved to a neighborhood with a crime risk that is lower than in the previous neighborhood of residence.

This leaves the question whether the process of gathering information or the weakening tendency for wishful thinking eventually leads to unbiased risk perceptions. To be able to say something to this effect, one needs to make an assumption about the risk perception of incumbent residents (those living in the area for more than 10 years). On the one hand, incumbent residents may have less distorted beliefs because they have better information or suffer less from wishful thinking than movers. If so, beliefs of those who moved into the neighborhood become more correct if they converge to the beliefs of the incumbent residents. On the other hand, biased risk perceptions need not be temporary, and risk perceptions could still be biased even after many years of living in the same neighborhood. A discussion of whether incumbent residents have unbiased risk perceptions is outside the scope of this paper.

\section{Empirical specification}

In our empirical analysis, we examine whether and how risk perceptions change with time since the date an individual moves to a different neighborhood. Our aim is to estimate the effect of length of time spent in a neighborhood on the perception of the crime risk in this neighborhood. Our empirical strategy is based on following cohorts of movers, and we examine how their perception of crime risk changes over successive survey years. In our estimation, we control for cohort fixed-effects for annual cohorts of movers, and for time trends in crime risk perception at the neighborhood level. Specifically, we estimate regression models of the following type:

$$
y_{i}=\text { time here }_{i} \beta+\text { incumbent }_{i} \gamma+X_{i}^{\prime} \lambda+I_{c}{ }^{\prime} \mu+\alpha_{n, t}+\varepsilon_{i}
$$

where outcome variable $y_{i}$ measures perceptions of crime in the neighborhood; $i$ indexes persons; time here ${ }_{i}$ measures time since move date to the current address for up to ten years ( 
time here $_{i}$ is set to zero for incumbent residents); incumbent $_{i}$ is a binary indicator for persons who have lived at their current address for more than ten years; $X_{i}$ is a vector of individual characteristics; $I_{c}$ is a vector of binary indicators for annual cohorts of movers, e.g. for persons who have moved to the current address in the year $c ; \alpha_{n, t}$ is a vector of interaction terms of neighborhoods and survey years, i.e. for individuals who lived in neighborhood $n$ in survey year $t ; \beta$ and $\gamma$ are parameters; $\lambda$ and $\mu$ are vectors of parameters; $\varepsilon_{i}$ is an individual specific error term. We cluster the standard errors at the level of the neighborhood.

The main parameter of interest is $\beta$, which represents a linear trend of how perceptions of crime change with time since the date of moving to the current neighborhood. Estimation coefficients for $\beta$ can be interpreted as causal effects if the exogeneity assumption below holds:

$$
E\left[\varepsilon_{i} \mid \text { time here }_{i}, \text { mover }_{i} X_{i}, \mathrm{I}_{c}, \alpha_{n, t}\right]=0
$$

This assumption could be violated if unobserved determinants of risk perception in $\varepsilon_{i}$ are correlated with explanatory variables. In the following, we discuss whether the exogeneity assumption is plausible within the context of our study. We discuss possible violations of this assumption, and how we can address these violations. We focus on three possible violations: 1) differential trends in risk perception between movers and incumbent residents, 2) the effects of selective attrition, and 3 ) the direct effect of time.

In our empirical strategy, we control for time trends in crime risk perception at the neighborhood level. A violation of the exogeneity assumption could be caused by different time trends in risk perceptions between movers and incumbent residents. Our estimation problem is akin to a classic problem in the empirical analysis of panel data and repeated crosssection data, namely how to disentangle the effects of age, cohorts and time. In our analysis, time since the move date takes the role of age, the year of move defines cohorts, and survey years define time. As is well known, age, time and cohort effects cannot be disentangled without further assumptions. In our example, we need to make assumptions either about time trends in risk perception or about cohort effects. Regression equation (2) is based on the assumption that time trends are the same for incumbent residents and for different cohorts of movers in the same neighborhood. Formally, we assume:

$$
\alpha_{n, t, \text { incumbents }}=\alpha_{n, t, \text { cohort } 1998}=\alpha_{n, t, \text { cohort } 1999}=\ldots=\alpha_{n, t, \text { cohort } 2011}
$$

This assumption is similar to the assumption that for example Borjas (1995) uses in a study on immigrant wages where he assumes that underlying trends for immigrant wages are the same 
as underlying trends for the wages of natives. Our question on risk perception refers to the perceived frequency of crime in the neighborhood. Thus, we assume that changes in crime risk at the neighborhood level do not systematically affect incumbent residents and different cohorts of movers in different ways.

We consider the assumption in equation (4) to be generally plausible. However, there are specific situations for which this assumption could be violated, e.g. if movers of a specific moving cohort disproportionally moved into a newly built part of the neighborhood that subsequently followed a different time trend in crime. While we cannot control for different time trends at a geographical level even smaller than neighborhoods, we conduct two robustness tests for the plausibility of assumption (4).

The first robustness test is to control for time trends in crime risk perceptions at a geographical level higher than the neighborhood. Instead of controlling for time trends at the neighborhood level, we control for time trends at the municipality or national level. If estimation results for the effect of time since the move date do not differ much between these alternative specifications, then this suggests that our results are robust to the specific geographical level of the time trends.

The second robustness test is to replace assumptions about time trends by assumptions about cohort effects. Specifically, we estimate regression equation (2) without cohort effects. Thus, we compare respondents who live in the same neighborhood in the same survey year, but who have lived there for different lengths of time. This specification assumes that there are no systematic differences in risk perceptions between those who moved in different years. This assumption could be violated if those who moved for example during the great recession in 2009 are systematically different from those who moved in 2007 , before the great recession. However, if estimation results for specifications with and without cohort fixed-effects are similar, this suggests that the respective biases might not be large (or they move in the same direction). Based on estimation equation (2), we can also test whether cohort fixed-effects are jointly significant.

A second reason why the exogeneity assumption in equation (3) could be violated is selective attrition. During our study period, some respondents move away from their current address, and those who move away might be different from those who stay at their current address. Thus, time since the move date could be related to unobserved components of risk perception because of selective attrition. In our study, we address this problem by restricting the sample of movers to respondents who do not move between the date of the survey and the end of year 
2011. ${ }^{6}$ By restricting the sample of movers to those who will not move again during our study period, we make sure that movers in all survey years are drawn from the same population. In this way, we exclude any bias from selective attrition. The effects of attrition that took place before the start of our study period in the year 2008 are captured by the cohort fixed-effects.

A third possible source of violation of the exogeneity assumption is caused by time itself. With increasing time since the move date, individuals become older. Age can affect risk perceptions. We address this issue by including age and age squared as explanatory variables in the estimation equation as well as other personal characteristics, including hou sehold size and labor force participation. ${ }^{7}$

\section{Data}

The source of data on perception of crime risk is the Netherlands Crime Survey (IVM). The IVM is an annual survey among some 200,000 randomly selected respondents in odd years and about 50,000 respondents in even years. Respondents are 15 years of age or older. The interviews are conducted from September 15 to December 31. Respondents are invited to participate in a letter. They can choose to complete the survey online or on paper. If they do not respond, they are asked to complete the survey in a telephone interview or, if that does not work out, in a face-to-face interview. Overall, the response rate is about 40 percent. The survey is based on a repeated cross section design. Relative to size of population (16 million), the IVM is one of the largest, if not the largest, crime survey in the world. We pool the four waves of the survey for the years $2008,2009,2010,2011 .^{8}$

Constructing the history of places of residence of respondents is facilitated by the fact that the sampling frame of the survey is the population register (Gemeentelijke Basisregistratie). In the population register, which is administered by municipalities, demographic details for each individual citizen are recorded, including the history of places of residence, going back to 1995.

\footnotetext{
${ }^{6}$ For incumbent residents, we do not exclude future movers from the sample. Selective attrition for incumbent residents does not bias our results because the time since the move date variable for incumbent residents is zero, and does not vary between survey years.

${ }^{7}$ Personal crime risk for movers is negatively related to the time since the move date (Xie and McDowall 2008). Risk-enhancing factors for those who moved recently include having relatively many newly purchased products in the home and not yet knowing neighbors who can keep an eye on one's property when away from home. Perception of neighborhood risk and personal risk may not be independent: individual experiences with crime may feed into perceived neighborhood risk. This could lead to a bias in perception of neighborhood risk that is negatively related to the time since the move date. As a consequence, our results present a lower bound of the effect of time since the move date on perception of neighborhood crime risk.

${ }^{8}$ Earlier waves of the national crime survey cannot be used because of comprehensive changes in sampling design and in the questionnaire in 2008. The survey was changed again after 2011, making later waves incomparable as well.
} 
We merge these records from the population register back on the survey data. We examine movers who moved to a different neighborhood during the last 10 years before the survey. The earliest cohort moved in 1998; the latest cohort moved in 2011.

Part of the survey relates to 'neighborhood problems'. Respondents are asked about their perception of the prevalence of crimes in the neighborhood of residence based on a verbal assessment of likelihood. The exact question is: Can you indicate whether in your view [crime type] occurs frequently, occasionally or almost never in your neighborhood? We select the following crime types: bicycle theft, burglary, theft from car and violent crime. ${ }^{9}$ For our main specification, the outcome variable is a binary indicator which is one if a respondent answers 'almost never' and zero otherwise. In the sensitivity analysis, we show that using all three answer categories (using ordered logit) produces qualitatively similar results. In the baseline specification, we treat the answer "don't know" as missing. In the sensitivity analysis, we show that our results are robust if we control for "don't know" answers with a Heckman selection model.

Respondents may not answer questions about the neighborhood crime risk accurately and thoughtfully if the questions are not incentivized (Loughran et al. 2014) - even though untruthful reporting has been found to be less important for well-defined events that are relevant to respondents' lives (Manski 2004), such as crime. In the real world, mistaken beliefs carry a cost in terms of a higher chance of becoming a victim of crime; in a survey such costs are absent. As we show in Figure 1, the responses have face validity: the perceived prevalence of a crime is related to its rate of occurrence. If the prevalence of victimization of crime is higher in a municipality, then fewer people think that it is rare, and vice versa. This holds for each of the four crime types. Although the time period we consider is too short to examine whether this also holds across time, this relationship has been shown elsewhere (Innes 2011). As a further check on the accuracy of the elicited beliefs, we analyze avoidance behavior. This is informative if questions about actual behavior are less likely to suffer from an incentive bias than questions about beliefs, which seems a reasonable assumption. If respondents act on their beliefs, then we should see changes in their beliefs reflected in changes in avoidance behavior. Respondents are asked whether they avoid unsafe places in their neighborhood and whether they do not allow their children to go to some places in the neighborhood because of crime

\footnotetext{
${ }^{9}$ We exclude crime types that do not occur at a clear frequency, including graffiti, littering, and dog fouling. For reasons of exposition, we limit the number of crime types to four, excluding street robbery, for which we find similar patterns (results available upon request).
} 
concerns. The outcome variable is a binary indicator which is one if a respondent answers 'yes, frequently' and zero otherwise. ${ }^{10}$

\section{[FIGURE 1]}

Another challenge is the inter-personal comparability of the elicited beliefs. Different respondents may not interpret the verbal assessment of likelihood in the same way. In our analysis, we follow cohorts of movers over time. We compare beliefs across time rather than across individuals. Since we keep the composition of (the randomly selected samples of) the cohorts the same, it is as if we follow a representative individual over time. In this sense, our analysis does not rest on inter-personal comparisons of beliefs. That leaves the assertion that the responses are intra-personally comparable. A potential concern is a shift in reference point from the previous to the current place of residence. The survey questions do not provide an explicit reference point for the risk assessment. If a shift in reference point occurs, then its effect depends on how the crime rate in the previous place of residence compares to the current place of residence. In the empirical analysis, we check for a shift in reference point by allowing the change in perceptions to vary between moves from relatively low-crime areas to relatively high-crime areas and vice versa. We also analyze avoidance behavior, which is likely to be at least partly driven by beliefs. If a change in avoidance behavior corresponds with the observed change in beliefs, then this makes it less likely that the change in beliefs is simply the result of a change in reference point when responding to survey questions.

In line with the survey questions about perception of the crime risk, the analysis is conducted at the level of the neighborhood. We use the definition of a neighborhood provided by Netherlands Statistics. In 2011, the Netherlands had 2,572 neighborhoods. The average population of a neighborhood was 6,475. A small municipality like Ten Boer (population of 7,400) has two neighborhoods; a provincial capital like Groningen (population of 200,000) has 10 neighborhoods; a large city in the densely populated western part of the country like The Hague (population of 500,000) has 44 neighborhoods. We do not know whether the formal definition of a neighborhood corresponds to the term used by the survey respondents. Colloquial use of the term neighborhood may relate to an even lower level of aggregation. The data do not

\footnotetext{
${ }^{10}$ We focus on avoidance behavior in the neighborhood. We do not consider preventive behaviors related to the individual's own home, such as leaving lights on when not at home, since changes in perceptions of the neighborhood crime risk are likely to differ from changes in perceptions of the individual risk (Tyler 1980). Moreover, people who have just moved may be more careful about their own home simply because it was recently acquired.
} 
allow us to conduct the analysis at a level lower than the neighborhood defined by Netherlands Statistics.

Our data include 550,760 respondents. In the sample used for the baseline estimation (column (1) in Table 2) we exclude 106,637 respondents because they respond "don't know" on the question about perceived neighborhood risk; 1,688 respondents were excluded because they refuse to answer this question. We exclude 15,414 respondents who moved after the interview date and 908 respondents for whom the neighborhood of residence is unknown. This leaves an estimation sample of 425,593 respondents. As stated before, we discuss how robust our findings are to excluding the answer category "don't know" in the sensitivity analysis.

Table 1 presents the summary statistics. The first two columns relate to the subsample of 116,699 respondents who moved at least once in the last 10 years, the next two columns to the full estimation sample. Movers are on average more likely to be young, well-educated, to have paid work and live in an apartment. The differences are generally small. The last move of those who moved at least once in the last 10 years is on average about five years (58 months) ago. Some 40 to 50 percent of respondents believe that burglary, bicycle theft and theft from car occur rarely in their neighborhood, for violent crime about 80 percent hold this belief.

\section{[TABLE 1]}

\section{Estimation results}

In this section, we present the estimation results and conduct a number of sensitivity tests (we defer a discussion of the interpretation of results to the next section).

\subsection{Graphical evidence: cohort trends}

As a first step, we graphically analyze the effect of time since the move date on perceptions of the neighborhood crime risk for different cohorts of movers. We estimate the following equation:

$$
y_{i}=I_{c} T_{t} \beta+X_{i}^{\prime} \lambda+\alpha_{n, t}+\varepsilon_{i}
$$

$I_{c} T_{t}$ is an interaction of moving cohort and survey year, e.g. the 1998 moving cohort in the survey year 2008. The coefficient $\beta$ represents how risk perceptions of specific moving cohorts in a specific survey year differ from risk perceptions of incumbent residents with the same observed characteristics in the same neighborhood and survey year.

[FIGURE 2] 
The upper four graphs in Figure 2 show the estimation results for the four different crime types. The vertical axes show the percentage of movers who think that a crime is rare in the neighborhood relative to incumbent residents. The horizontal axes show the time since the last move in calendar years. The outcome variable in the upper left figure is a binary indicator for "bicycle theft occurs almost never in this neighborhood". We find close to all cohort curves to be downward sloping. This suggests that the longer the time since the move date, the less likely people are to perceive prevalence of bicycle theft as rare - relative to the incumbent residents. In other words, people perceive the neighborhood prevalence of bicycle theft to be greater, the longer ago they moved. Clearly, this is after the initial adjustment of beliefs at the time of the move: we only focus on what happens after. The changes in perception of the rate of bicycle theft continue for up to 10 years. As the other three graphs for perceptions of crime risk show, perceived prevalence of burglary, theft from car and violence in the neighborhood all follow a similar pattern.

The lower two graphs in Figure 2 show that adjustment in avoidance behavior in the neighborhood is in line with the observed changes in beliefs. The longer people live in a neighborhood, the more careful they become. This suggests that the changes in beliefs that we find are real in the sense that they go together with behavioral changes.

\subsection{Relation with the crime rate in the previous place of residence}

Next, we investigate adjustment in beliefs by the nature of the change in the neighborhood crime risk resulting from a move. As discussed in Section 2, this is essential for distinguishing the use of the anchoring-and-adjustment heuristic from other theories of belief formation. We distinguish four types of moves, depending on the level of crime in the previous and in the current neighborhood of residence: from safe to safe, from safe to unsafe, from risky to safe and from risky to risky. Safe neighborhoods have a rate of victimization of crime below the national average; risky neighborhoods have a rate of victimization of crime above the national average. We estimate the average trend across cohorts, i.e. the coefficients are estimated including cohort-fixed effects. The estimation equation is as in equation (2), but we substitute the linear term for time since the move date with a vector of binary indicators, with $\beta$ representing a set of yearly dummies rather than one coefficient. We take those who moved less than 12 months ago as the reference group (in the graphs referred to as 'recent movers').

\section{[FIGURE 3]}

The upper four graphs in Figure 3 show the adjustment in perception of crime risk for the different types of moves. The risk adjustment is essentially similar for the four types of moves 
and this holds for each crime type. In other words, the risk adjustment is found to be independent of the crime rate in the previous place of residence relative to the new place of residence. In all cases, the adjustment is substantial. In 10 years' time, the percentage of movers who think that bicycle theft is rare has declined by 8 percentage points $\left(11\right.$ percent). ${ }^{11}$ For burglary, the adjustment is 14 percentage points (30 percent), for theft from car it is 12 percentage points (18 percent), and for violence 10 percentage points (13 percent). ${ }^{12}$ In line with these results, we also find that avoidance behavior always goes up after a move, regardless of the type of move. The adjustment is even larger, in both cases about 66 percent.

\subsection{Parametric evidence}

In Table 2, we test whether the observed change in perceived crime risk with time since the move date meets the standards of statistical significance. We estimate equation (2), where time since the last move enters as a linear variable. Again, we distinguish four types of moves, depending on the crime rate in the current and previous place of residence.

The first two columns of Table 2 present the estimation results for the perceived prevalence of bicycle theft in the neighborhood. Whether including cohort-fixed effects or not, we find a negative effect of time since the move date on risk perceptions that is statistically highly significant. When dividing the estimated coefficients by 1,000 , multiplying by 12 (months to years) and by 9 (number of years covered in Figure 3), we obtain percentage point decreases that are similar in size to those in Figure 3. The coefficients for the four types of moves are roughly similar. The results confirm those we found in Figure 3. Similarly, we find statistically significant effects of time the since move date on the perception of the risk of burglary, theft from car and violent crime (columns 3-8). Again, the effects are similar in size to those we found in Figure 3. Finally, the changes in avoidance behavior with time since the move date in the specification with cohort-fixed effects are also found to be statistically significant at conventional levels, and comparable in size with the results shown in Figure 3 (columns 9-12).

\section{[TABLE 2]}

\section{$5.4 \quad$ Heterogeneity}

In Figure 4, we allow the effect of time since the move date on the perceived risk to vary between different groups of movers: home owners and renters, young and old, high and low

${ }^{11} 0.08-0.03$ divided by the average of 0.47 , see the summary statistics.

${ }^{12}$ The differences in the size of the adjustment should be interpreted with caution, as the verbal risk assessment may have been interpreted differently across crime types. 
levels of education, males and females, and infrequent and more frequent movers. The beliefs are estimated relative to people who moved less than one year ago ('recent movers').

\section{[FIGURE 4]}

In all cases, we find a similar change in perceived risk with time since the move date as reported previously. We only report estimates for perceived risk of bicycle theft; the results for the four other crime types are similar.

\section{[FIGURE 5]}

In Figure 5, we also allow the effect to differ by distance of move. We distinguish four types of moves: moves within the same neighborhood, moves to another neighborhood but within the same municipality, moves to another municipality but within the same province, and moves to a different province (in 2001, the Netherlands had 12 provinces and 418 municipalities). We find the adjustment in risk perceptions to be somewhat lower for moves within the same neighborhood compared to moves to a different neighborhood. The difference in adjustment after 10 years for moves within the neighborhood versus moves to a different province is statistically significant at the 1 percent level for all four crime types.

\subsection{Sensitivity analysis}

We conduct a number of tests to analyze the sensitivity of our results to alternative assumptions and alternative empirical specifications. As discussed in Section 3, our empirical models rely on the assumption that time trends in the crime rate are the same for incumbent residents of a neighborhood and for those who moved into that neighborhood. A formal definition of this assumption is given in equation (4). As a sensitivity test, we control for time trends in crime risk perceptions at geographical levels other than the neighborhood: the national level and the municipality level. The results for these two alternative specifications are shown in Table A1 and $\mathrm{A} 2$ in the Appendix. Results in both tables are very similar to the baseline specification in Table 2. Risk perceptions become strongly and statistically significantly more negative with increasing time since the move date, while avoidance behavior goes up. These results suggest that our results are robust to alternative specifications of time trends.

We reduced the responses to questions about crime perceptions from the three presented in the survey (frequently, occasionally, or almost never) to a binary indicator of whether a crime occurs almost never in the neighborhood. We use the binary indicator as an outcome variable in linear probability models. As a robustness check, we also estimate ordered logit models for all three outcome categories. We are not able to estimate ordered logit models with a complete 
set of neighborhood by year interaction variables due to an incidental parameter problem. Instead, we estimate a model with national time trends. Estimation results for ordered logit models are shown in Table A3. Coefficients from ordered logit models are not directly comparable with coefficients from linear regressions, given the use of three rather than two answer categories. Still, the estimation results from ordered logit models and from linear probability models point in the same direction. Crime risk perceptions decrease with increasing time since the move date, and this relationship is statistically significant.

A substantial fraction of respondents answered "don't know" on questions about the perceived crime risk in the neighborhood. So far, we excluded this response category. It could be that the share of respondents in this category is related to time since the move date, and should this be so, those who switch to (or from) an answer in another category may be different from those who have always remained in the other response categories. In that case, our results may be biased. As a robustness check, we re-estimate our baseline specification including a Heckman selection model that takes sample selection caused by "don't know" answers into account. In the first stage, we estimate the probability of giving an answer other than "don't know." As an instrumental variable for giving a valid answer about crime risk perception, we use a binary indicator for responding "don't know" on a different question in the survey: whether playgrounds are sufficiently available in the neighborhood. The model can only be estimated with a national time trend in the crime rate. Estimation results for Heckman selection models are shown in Table A4 in the Appendix. We find that "don't know" answers about crime risk perception in the neighborhood strongly and significantly decrease with increasing time since the move date. Still, estimation results for crime risk perceptions are very similar to those based on a national rather than a neighborhood crime trend reported in Table A1 and also to the baseline specification in Table 2. Crime risk perceptions strongly and significantly decrease with increasing time since the move date.

The level of crime in a neighborhood is measured based on the frequency of victimization of crime in our sample. For neighborhoods with few observations, crime rates could be measured imprecisely, leading to an inaccurate classification of neighborhoods into having a crime rate that is above or below the national average. As a robustness check, we re-estimate our model while restricting the sample to respondents with at least 100 observations in both their current and previous neighborhood. Estimation results are shown in Table A5. Again, similar to the baseline specification, we do not find any substantial differences in the effect of time since the 
move date on risk perceptions by type of move. Thus, this finding cannot be explained by measurement error in the classification of neighborhoods into 'risky' or 'safe'.

\section{Discussion}

In summary, we find a pattern of an upwards adjustment in neighborhood crime risk perceptions after a move. Our results are independent of the specific motive to move (people younger than 30 often move for work or study; older people often out of a preference for a better home or neighborhood, see WoON survey 2012), from differences in the capability of dealing with risk (given the results for educational attainment, which is related to cognitive ability, see Dohmen et al. 2010), from gender differences and, perhaps most surprisingly, from being in the position to learn from previous moves. The size of the adjustment in beliefs differs by distance of move. It is smaller for moves within the same neighborhood, and it is larger for moves to a different province.

These findings violate the assumption of rational expectations and suggest the presence of a judgmental bias. If people are well-informed, then changes in the perceptions of the population base rate over time should not differ between those who just moved into the neighborhood and those who moved longer ago. They all live in the same neighborhood after all; the underlying risk is the same.

An upwards adjustment in risk perceptions after moving house fits with the availability heuristic discussed in Section 2. People may base their perceptions of the crime risk on the ease with which negative experiences of crime in the new place of residence can be brought to mind. The stock of crime-related experiences increases over time, resulting in a progressively greater perceived risk of crime. More generally, if this is how potential victims' beliefs evolve, then perceptions of crime risk are primarily based on recent or particularly disturbing direct and indirect experiences with crime in their neighborhood rather than statistical information such as reported crime rates. This is consistent with the finding that adjustment in risk perceptions is lower for moves within the same neighborhood than for moves to a different neighborhood: the stock of experiences built up in the previous place of residence is partly relevant for nearby moves but not for moves further away. The exceedingly long duration of the adjustment process could be related to the infrequent occurrence of victimization of crime: for most people, the stock of direct experiences expands only slowly. The data do not, however, allow us to disentangle the channels by which beliefs are changed. 
Our results contrast with the anchoring-and-adjustment heuristic. We do not find the adjustment to differ depending on the crime risk in the previous place of residence (the 'anchor') relative to the new place of residence. These results also suggest that the reference point that respondents use to answer questions about the neighborhood crime risk does not gradually shift from the previous to the current place of residence after having moved (see Section 4 for a discussion). Such a shift would have been apparent in a different adjustment for different types of moves.

Over-optimistic beliefs about the crime risk in the neighborhood one wants to move to, a variant of the winners' curse that we discussed in Section 2, is not a likely explanation of our findings either. This bias should have less of an effect for people who have limited choice of where to live. In the Netherlands, this holds for most renters. They cannot simply move to the place of their liking. The reason is that almost 70 percent of renters live in rent-controlled homes provided by social housing foundations (one in three of all homes are in this sector). Due to the highly restricted supply of this type of housing, prospective tenants often need to compromise many of their wishes, including their preferred neighborhood. We found very similar patterns for the evolution of risk perceptions for owners and renters. This contradicts the winner's curse explanation.

Other than the use of the availability heuristic in making a judgment of the crime risk, our results may be related to the mediator of the change in crime risk that we use in our analysis: moving house. As discussed in Section 2, people may have a tendency to justify the decision to move by casting characteristics of their new living environment in too positive a light. This tendency may diminish over time, resulting in the same pattern in beliefs. This choicesupportive bias also fits with the difference in adjustment by distance of move. For those moving within the same neighborhood, it does not make sense to present too rosy a picture of the crime rate in the locality they have been living in for some time already. This would only make sense for the crime rate in a different locality. A bias resulting from cognitive dissonance and a bias from use of the availability heuristic are observationally equivalent. The upwards adjustment in risk perceptions may be the result of both gathering information about what goes on in the neighborhood and a diminishing tendency to cast everything in too positive a light. Future research should show which of the two mechanisms is at work.

A lessening impact of the choice-supportive bias implies that crime risk perceptions become less distorted over time. Use of the availability heuristic also implies a diminishing bias if we believe that the ability to draw upon a greater stock of direct and indirect experiences of crime 
makes people better informed about what goes on in their neighborhood. Both implications for the degree to which beliefs are distorted are in line with the finding that risk perceptions of movers converge towards those of the incumbent residents. Under the above assumption about the value of gained experiences with crime, it should be noted that the convergence of beliefs only suggests less distortion, not that crime risk perceptions converge to the correct value. As we discussed in Section 2, beliefs of the incumbent residents may well be off (even though we find differences in crime risk perceptions to correspond with differences in actual victimization rates in Section 4). This means that our findings do not necessarily contradict with the popular belief that people tend to overestimate the crime risk, and the finding that subjective probabilities are generally higher than objective probabilities within the context of crime risk.

Our findings have important implications for the understanding of the causes of crime. For crime to occur, a potential victim needs to offer an opportunity. With a few notable exceptions, this demand-side of the crime equation has been largely ignored since the 1980s. We do not only bring victim behavior back into focus, but go beyond the existing models and empirical evidence by looking at how potential victims actually deal with crime. In previous work, all exposure to the crime risk was assumed to be deliberate, i.e. the result of weighing cost and benefits based on perfect information. We show that one key element in precautionary decision making, assessment of the crime risk, can be severely biased for an extensive period of time.

Our paper opens avenues for an alternative way of lowering the cost of crime to society, namely reducing the number of readily available criminal opportunities by altering victim behavior. If potential victims inadvertently expose themselves to crime risk because their beliefs and precautions are off, then this provides another rationale for intervening in precautionary behavior, next to the traditional argument of externalities emanating from private victim precaution. Because of the high pecuniary and particularly the high emotional burden of some crimes, preventing mistakes can have a high payoff. Targeting victim rather than offender behavior may be a more cost-effective way of lowering crime, as has been shown in the cases of regulation of car security and of home security discussed in the introduction. Such interventions can improve welfare, because they do not simply redistribute crime from wellprotected to less well-protected targets. Greater victim precaution can deter potential offenders from engaging in crime at least temporarily because they cannot costlessly and instantaneously shift towards alternative criminal opportunities. 


\section{References}

Acquisti, Alessandro and Catherine Tucker, 2011, Guns, privacy, and crime, unpublished manuscript, Carnegie Mellon University/MIT Sloan School of Business.

Akerlof, G.A. and W.T. Dickens, 1982, The economic consequences of cognitive dissonance, American Economic Review, 72, 307-319.

Amodio, Francesco, 2013, Crime protection investment spillovers: theory and evidence from the city of Buenos Aires, unpublished manuscript, Universitat Pompeu Fabra, Barcelona.

Ayres, Ian and Steven D. Levitt, 1998, Measuring positive externalities from unobservable victim precaution: an empirical analysis of Lojack, Quarterly Journal of Economics, 113 (1), 43-77.

Baumeister, Roy F., Ellen Bratslavsky, Catrin Finkenauer, Kathleen D. Vohs, 2001, Bad is stronger than good, Review of General Psychology, 5 (4), 323-370.

Bernasco, Wim, Richard Block and Stijn Ruiter, 2013, Go where the money is: modeling street robbers' location choices, Journal of Economic Geography, 13, 119-143.

Borjas, George (1995), Assimilation and changes in cohort quality revisited: what happened to immigrant earnings in the 1980s? Journal of Labor Economics, 13 (2), 201-245.

Clotfelter, Charles T., 1977, Public services, private substitutes, and the demand for protection against crime, American Economic Review, 67 (5), 867-77.

Cook, Philip J., 1986, The demand and supply of criminal opportunities, Crime and Justice, 7, 1-27.

Cook, Philip J. and Jens Ludwig, 2006, The social cost of gun ownership, Journal of Public Economics, 90 (1), 379-391.

Cook, Philip J. and John MacDonald, 2011, Public safety through private action: an economic assessment of bids, The Economic Journal, 121, 445-62.

Cohen, Lawrence E. and Marcus Felson, 1979, Social change and crime trends: a routine activity approach, American Sociological Review, 44, 588-608.

Di Tella, Rafael, Sebastian Galiani, and Ernesto Schargrodsky, 2010, Crime inequality and victim behavior during a crime wave, in: R. Di Tella, S. Edwards and E. Schargrodsky (eds.), The economics of crime: lessons for and from Latin America, University of Chicago Press, 175-206.

Dijk, Jan J.M. van, 1994, Understanding crime rates. On the interactions between the rational choices of victims and offenders, British Journal of Criminology, 34 (2), 105-121

Dohmen, Thomas, Armin Falk, David Huffman, and Uwe Sunde, 2010, Are risk aversion and impatience related to cognitive ability?, American Economic Review, 100 (3), 1238-60.

Dominitz, Jeff, Charles F. Manski, 1997, Perceptions of economic insecurity. Evidence from the survey of economic expectations, Public Opinion Quarterly, 61, 261-287.

Ehrlich, Isaac, 1981, On the usefulness of controlling individuals: an economic analysis of rehabilitation, incapacitation and deterrence, American Economic Review, 71 (3), 307-322.

Ehrlich, Isaac, 1996, Crime, punishment, and the market for offenses, Journal of Economic Perspectives, 10 (1), 43-67.

Felson, Marcus and Erika Poulsen, 2003, Simple indicators of crime by time of day, International Journal of Forecasting, 19, 595-601. 
Gallagher, J., 2014, Learning about an infrequent event: evidence from flood insurance take-up in the United States, American Economic Journal: Applied Economics, 6 (3), 206-233.

Gonzalez-Navarro, M., 2013, Deterrence and geographical externalities in auto theft, American Economic Journal: Applied Economics, in press

Helsley, R.W. and W.C. Strange, 1999, Gated communities and the economic geography of crime, Journal of Urban Economics, 46 (1), 80-105.

Helsley, R.W. and W.C. Strange, 2005, Mixed markets and crime, Journal of Public Economics, 89, 1251-75.

Hjalmarsson, R., 2009, Crime and expected punishment: changes in perceptions at the age of criminal majority, American Law and Economics Review, 11 (1), 209-248.

Hui-Wen, K. and I.P.L Png, 1994, Private security: deterrent or diversion?, International Review of Law and Economics, 14 (1), 87-101.

Innes, Jennifer, 2011, Public perceptions, Chapter 5 in: Rupert Chaplin, John Flatley and Kevin Smith (eds.), Crime in England and Wales 2010/11, HOSB:10/11, Home Office, London, 83-100.

IVM (Integrale Veiligheidsmonitor), 2011, Dataset, Netherlands Statistics, The Hague.

Jackson, J., and E. Gray, 2010, Functional fear and public insecurities about crime, British Journal of Criminology, 50, 1-22.

Krumpal, I., H. Rauhut, D. Böhr, and E. Naumann, 2011, The framing of risks and the communication of subjective probabilities for victimizations, Quality and Quantity, 45, 1331-1348.

Manski, Charles, 2004, Measuring expectations, Econometrica, 72 (5), 1329-1376.

Lauritsen, Janet L. and Maribeth L. Rezey, 2013, Measuring the prevalence of crime with the National Crime and Victimization Survey, Bureau of Justice Statistics, US Department of Justice, Washington DC.

Lochner, Lance, 2007, Individual Perceptions of the Criminal Justice System, American Economic Review, 97 (1), 444-460.

Loughran, Thomas A., Ray Paternoster, and Kyle J. Thomas, 2014, Incentivizing responses to selfreport questions in perceptual deterrence studies: an investigation of the validity of deterrence theory using Bayesian truth serum, Journal of Quantitative Criminology, 30, 677-707.

Ours, Jan C. van, and Ben A. Vollaard, forthcoming, The engine immobilizer: a non-starter for car thieves, The Economic Journal.

Quillian, Lincoln and Devah Pager, 2010, Estimating risk: stereotype ampliciation and the perceived risk of criminal victimization, Social Psychology Quarterly, 73, 79-104.

Shavell, Steven, 1991, Individual precautions to prevent theft: private versus socially optimal behavior, International Review of Law and Economics, 11, 123-132.

Skogan, W.G. and M.G. Maxfield, 1981, Coping with crime. Individual and neighborhood reactions, Sage, London.

Slovic, Paul, 1987, Perception of risk, Science, 236 (4799), 280-285.

Slovic, P., B. Fischhoff, and S. Lichtenstein, 1987, Behavioral decision theory perspectives on protective behavior, chapter 1 in: N.D. Weinstein (ed.), Taking care. Understanding and encouraging self-protective behavior, Cambridge University Press, Cambridge, 14-41. 
Smith, V.K., D.H. Taylor, F.A. Sloan, F.R. Johnson and W.H. Desvouges, 2001, Do smokers respond to health shocks?, Review of Economics and Statistics, 83 (4), 675-687.

Tversky, A., and D. Kahneman, 1973, Availability: a heuristic for judging frequency and probability, Cognitive Psychology, 5, 207-232.

Tversky, A., and D. Kahneman, 1974, Judgment under uncertainty: heuristics and biases, Science, 185, $1124-1130$.

Tyler, Tom R., 1980, Impact of directly and indirectly experienced events: the origin of crime-related judgment and behaviors, Journal of Personality and Social Psychology, 39 (1), 13-28.

Vollaard, Ben A. and Jan C. van Ours, 2011, Does regulation of built-in security reduce crime? Evidence from a natural experiment, The Economic Journal, 121, 485-504.

Weisburd, D., E.R. Groff, and S. Yang, 2012, The criminology of place, Oxford University Press, New York.

Wonnacott, Ronald, and Thomas Wonnacott, 1985, Introductory Statistics, 4th edition, Wiley \& Sons, New York.

WoON Survey, 2012, Dataset, Netherlands Statistics, The Hague.

Xie, Min, and David McDowall, 2008, The effects of residential turnover on household victimization, Criminology, 46 (3), 539-75. 
Table 1. Summary statistics

\begin{tabular}{|c|c|c|c|c|}
\hline & \multicolumn{2}{|c|}{ Sample of movers } & \multicolumn{2}{|c|}{ Full sample } \\
\hline & Mean & $\begin{array}{r}\text { Standard } \\
\text { Dev. }\end{array}$ & M ean & $\begin{array}{r}\text { Standard } \\
\text { Dev. }\end{array}$ \\
\hline \multicolumn{5}{|l|}{ Victimization last 12 months } \\
\hline Any crime & 0.367 & 0.482 & 0.304 & 0.460 \\
\hline \multicolumn{5}{|l|}{ Risk perception } \\
\hline "Bicycle theft is rare in neighborhood" & 0.472 & 0.499 & 0.481 & 0.500 \\
\hline "Burglary is rare in neighborhood" & 0.431 & 0.495 & 0.393 & 0.488 \\
\hline "Theft from car is rare in neighborhood" & 0.544 & 0.498 & 0.542 & 0.498 \\
\hline "Violent crime is rare in neighborhood" & 0.762 & 0.426 & 0.796 & 0.403 \\
\hline \multicolumn{5}{|l|}{ Avoidance behavior } \\
\hline "Frequently avoids unsafe places in neighborhood" & 0.059 & 0.235 & 0.053 & 0.215 \\
\hline $\begin{array}{l}\text { "Frequently doesn't allow children to go to some } \\
\text { places in neighborhood because of crime concerns" }\end{array}$ & 0.119 & 0.324 & 0.096 & 0.207 \\
\hline \multicolumn{5}{|l|}{ Personal characteristics } \\
\hline Months since the move date & 58.197 & 35.613 & & \\
\hline Moved at least twice in last 10 years & 0.467 & 0.499 & & \\
\hline Age & 42.336 & 15.154 & 48.881 & 17.172 \\
\hline Female & 0.521 & 0.500 & 0.529 & 0.499 \\
\hline Household size & 2.651 & 1.256 & 2.712 & 1.240 \\
\hline Secondary education & 0.362 & 0.481 & 0.370 & 0.483 \\
\hline Tertiary education & 0.411 & 0.492 & 0.303 & 0.460 \\
\hline Education information missing & 0.015 & 0.123 & 0.016 & 0.124 \\
\hline Paid work for more than 12 hours per week & 0.676 & 0.468 & 0.553 & 0.497 \\
\hline Homeowner & 0.688 & 0.463 & 0.704 & 0.457 \\
\hline Residence in detached house & 0.139 & 0.346 & 0.186 & 0.389 \\
\hline Residence in townhouse & 0.497 & 0.500 & 0.548 & 0.498 \\
\hline Residence in apartment & 0.358 & 0.479 & 0.258 & 0.438 \\
\hline
\end{tabular}


Table 1. Summary statistics (continued)

\begin{tabular}{lrrrr}
\hline & \multicolumn{2}{c}{ Sample of movers } & \multicolumn{2}{r}{ Full sample } \\
\cline { 2 - 5 } & Mean & $\begin{array}{r}\text { Standard } \\
\text { Dev. }\end{array}$ & M ean & $\begin{array}{r}\text { Standard } \\
\text { Dev. }\end{array}$ \\
\hline Type of move by crime risk & & & & \\
From safe to safe neighborhood & 0.261 & 0.439 & 0.071 & 0.258 \\
From risky to safe neighborhood & 0.193 & 0.395 & 0.053 & 0.224 \\
From safe to risky neighborhood & 0.170 & 0.376 & 0.047 & 0.211 \\
From risky to risky neighborhood & 0.376 & 0.484 & 0.103 & 0.304 \\
Type of move by distance & & & & \\
Within same neighborhood & & & 0.184 & 0.388 \\
To different neighborhood in same municipality & 0.484 & 0.500 & 0.133 & 0.339 \\
To different municipality in same province & 0.339 & 0.473 & 0.096 & 0.295 \\
To different province & 0.177 & 0.382 & 0.049 & 0.215 \\
Number of observations & 116,699 & & 425,593 & \\
\hline
\end{tabular}

Notes. The sample of movers is restricted to respondents who have moved to a different neighborhood at least once in the last ten years. The sample size varies for different outcome variables. Sample statistics are for baseline estimation in Column (1) of Table 2. 
Table 2. Effect of time since the move date on risk perception and avoidance behavior, by level of crime in current and previous place of residence

\begin{tabular}{|c|c|c|c|c|c|c|}
\hline & \multicolumn{2}{|c|}{$\begin{array}{l}\text { "Bicycle theft is rare in } \\
\text { neighborhood" }\end{array}$} & \multicolumn{2}{|c|}{$\begin{array}{l}\text { "Burglary is rare in } \\
\text { neighborhood" }\end{array}$} & \multicolumn{2}{|c|}{$\begin{array}{c}\text { "Theft from car is rare in } \\
\text { neighborhood" }\end{array}$} \\
\hline & $\begin{array}{l}\text { Without } \\
\text { cohort FE } \\
\text { (1) }\end{array}$ & $\begin{array}{c}\text { With } \\
\text { cohort FE } \\
(2)\end{array}$ & $\begin{array}{l}\text { Without } \\
\text { cohort FE } \\
\text { (3) }\end{array}$ & $\begin{array}{c}\text { With } \\
\text { cohort FE } \\
(4)\end{array}$ & $\begin{array}{l}\text { Without } \\
\text { cohort FE } \\
\text { (5) }\end{array}$ & $\begin{array}{c}\text { With } \\
\text { cohort FE } \\
(6)\end{array}$ \\
\hline $\begin{array}{l}\text { Months since move } x \\
\text { move from safe to } \\
\text { safe neighborhood }\end{array}$ & $\begin{array}{l}-0.4176 * * * \\
(0.0933)\end{array}$ & $\begin{array}{l}-0.7311^{* * *} \\
(0.1754)\end{array}$ & $\begin{array}{l}-0.7956 * * * \\
(0.0889)\end{array}$ & $\begin{array}{l}-1.3738 * * * \\
(0.1692)\end{array}$ & $\begin{array}{l}-0.8522 * * * \\
(0.0861)\end{array}$ & $\begin{array}{l}-1.2206 * * * \\
(0.1688)\end{array}$ \\
\hline $\begin{array}{l}\text { Months since move } x \\
\text { move from risky to } \\
\text { safe neighborhood }\end{array}$ & $\begin{array}{l}-0.4936 * * * \\
(0.1031)\end{array}$ & $\begin{array}{l}-0.8083 * * * \\
(0.1772)\end{array}$ & $\begin{array}{l}-0.8123 * * * \\
(0.0949)\end{array}$ & $\begin{array}{l}-1.3921 * * * \\
(0.1713)\end{array}$ & $\begin{array}{l}-0.8631 * * * \\
(0.1132)\end{array}$ & $\begin{array}{l}-1.2311 * * * \\
(0.1937)\end{array}$ \\
\hline $\begin{array}{l}\text { Months since move } x \\
\text { move from safe to } \\
\text { risky neighborhood }\end{array}$ & $\begin{array}{l}-0.3799 * * * \\
(0.0975)\end{array}$ & $\begin{array}{l}-0.7072 * * * \\
(0.1747)\end{array}$ & $\begin{array}{l}-0.6996 * * * \\
(0.1180)\end{array}$ & $\begin{array}{l}-1.2714 * * * \\
(0.1823)\end{array}$ & $\begin{array}{l}-0.7778 * * * \\
(0.1140)\end{array}$ & $\begin{array}{l}-1.1439 * * * \\
(0.1890)\end{array}$ \\
\hline $\begin{array}{l}\text { Months since move } x \\
\text { move from risky to } \\
\text { risky neighborhood }\end{array}$ & $\begin{array}{l}-0.3779 * * * \\
(0.0705)\end{array}$ & $\begin{array}{l}-0.7077 * * * \\
(0.1572)\end{array}$ & $\begin{array}{l}-0.5693 * * * \\
(0.0831)\end{array}$ & $\begin{array}{l}-1.1449 * * * \\
(0.1583)\end{array}$ & $\begin{array}{l}-0.6280 * * * \\
(0.0749)\end{array}$ & $\begin{array}{l}-0.9980 * * * \\
(0.1596)\end{array}$ \\
\hline$p$-value cohort-FE $=0$ & & 0.1059 & & 0.0065 & & 0.1104 \\
\hline $\begin{array}{l}\text { Number of } \\
\text { observations }\end{array}$ & 425,593 & 425,593 & 447,487 & 447,487 & 428,190 & 428,190 \\
\hline R-Squared & 0.022 & 0.022 & 0.043 & 0.043 & 0.023 & 0.023 \\
\hline
\end{tabular}

Notes. Results show coefficients for linear regression as in Equation (2). Coefficients are multiplied by a factor of 1,000. A neighborhood is denoted as safe if the crime rate is below average. A neighborhood is denoted as risky if the crime rate is above average. Coefficients for age, age squared, female, household size, education, labor force participation, home ownership, two or more moves during last 10 years, type of residence, for moves from a risky to a safe municipality, for moves from a safe to a risky municipality, for moves from a risky to a risky municipality, survey mode, cohort fixed effects, and fixed effects for neighborhood and year interactions are not shown. Robust standard errors (clustered at neighborhood level) are given in parentheses. Statistical significance at $* * * 1 \% * * 5 \%$ $* 10 \%$ level. 
Table 2. Effect of time since the move date on risk perception and avoidance behavior, by level of crime in current and previous place of residence (continued)

\begin{tabular}{|c|c|c|c|c|c|c|}
\hline & \multicolumn{2}{|c|}{$\begin{array}{l}\text { "Violent crime is rare in } \\
\text { neighborhood" }\end{array}$} & \multicolumn{2}{|c|}{$\begin{array}{l}\text { "Frequently avoids } \\
\text { unsafe places in } \\
\text { neighborhood" }\end{array}$} & \multicolumn{2}{|c|}{$\begin{array}{l}\text { "Frequently doesn't allow } \\
\text { children to go to some } \\
\text { places in neighborhood" }\end{array}$} \\
\hline & $\begin{array}{l}\text { Without } \\
\text { cohort FE } \\
(7)\end{array}$ & $\begin{array}{c}\text { With } \\
\text { cohort FE } \\
(8)\end{array}$ & $\begin{array}{l}\text { Without } \\
\text { cohort FE } \\
\text { (9) }\end{array}$ & $\begin{array}{c}\text { With } \\
\text { cohort FE } \\
(10)\end{array}$ & $\begin{array}{l}\text { Without } \\
\text { cohort FE } \\
(11)\end{array}$ & $\begin{array}{l}\text { With } \\
\text { cohort } \\
\text { FE } \\
(12)\end{array}$ \\
\hline $\begin{array}{l}\text { Months since move } x \\
\text { move from safe to } \\
\text { safe neighborhood }\end{array}$ & $\begin{array}{l}-0.3803 * * * \\
(0.0644)\end{array}$ & $\begin{array}{l}-1.0049 * * * \\
(0.1514)\end{array}$ & $\begin{array}{l}0.1286 * * * \\
(0.0391)\end{array}$ & $\begin{array}{l}0.2865 * * * \\
(0.0933)\end{array}$ & $\begin{array}{l}0.3495^{* * *} \\
(0.0730)\end{array}$ & $\begin{array}{l}0.7415^{* * *} \\
(0.1595)\end{array}$ \\
\hline $\begin{array}{l}\text { Months since move } x \\
\text { move from risky to } \\
\text { safe neighborhood }\end{array}$ & $\begin{array}{l}-0.3399 * * * \\
(0.0912)\end{array}$ & $\begin{array}{l}-0.9647 * * * \\
(0.1692)\end{array}$ & $\begin{array}{l}0.0833^{*} \\
(0.0435)\end{array}$ & $\begin{array}{l}0.2421 * * \\
(0.0951)\end{array}$ & $\begin{array}{l}0.2718 * * * \\
(0.0834)\end{array}$ & $\begin{array}{l}0.6618^{* * *} \\
(0.1670)\end{array}$ \\
\hline $\begin{array}{l}\text { Months since move } x \\
\text { move from safe to } \\
\text { risky neighborhood }\end{array}$ & $\begin{array}{l}-0.5114 * * * \\
(0.1055)\end{array}$ & $\begin{array}{l}-1.1116 * * * \\
(0.1722)\end{array}$ & $\begin{array}{l}0.0947 \\
(0.0591)\end{array}$ & $\begin{array}{l}0.2469 * * \\
(0.0974)\end{array}$ & $\begin{array}{l}0.4956 * * * \\
(0.1248)\end{array}$ & $\begin{array}{l}0.8754 * * * \\
(0.1876)\end{array}$ \\
\hline $\begin{array}{l}\text { Months since move } x \\
\text { move from risky to } \\
\text { risky neighborhood }\end{array}$ & $\begin{array}{l}-0.4590 * * * \\
(0.0781)\end{array}$ & $\begin{array}{l}-1.0643 * * * \\
(0.1470)\end{array}$ & $\begin{array}{l}0.0026 \\
(0.0455)\end{array}$ & $\begin{array}{l}0.1554 * \\
(0.0889)\end{array}$ & $\begin{array}{l}0.1582 * \\
(0.0891)\end{array}$ & $\begin{array}{l}0.5399 * * * \\
(0.1620)\end{array}$ \\
\hline $\mathrm{p}$-value cohort-FE $=0$ & & 0.0038 & & 0.0878 & & 0.1029 \\
\hline $\begin{array}{l}\text { Number of } \\
\text { observations }\end{array}$ & 410,675 & 410,675 & 338,664 & 338,664 & 192,678 & 192,678 \\
\hline R-Squared & 0.022 & 0.022 & 0.018 & 0.018 & 0.019 & 0.019 \\
\hline
\end{tabular}

Notes. Results show coefficients for linear regression as in Equation (2). Coefficients are multiplied by a factor of 1,000. A neighborhood is denoted as safe if the crime rate is below average. A neighborhood is denoted as risky if the crime rate is above average. Coefficients for age, age squared, female, household size, education, labor force participation, home ownership, two or more moves during last 10 years, type of residence, for moves from a risky to a safe municipality, for moves from a safe to a risky municipality, for moves from a risky to a risky municipality, survey mode, cohort fixed effects, and fixed effects for neighborhood and year interactions are not shown. Robust standard errors (clustered at neighborhood level) are given in parentheses. Statistical significance at *** $1 \% * * 5 \%$ $* 10 \%$ level. 
Figure 1. Actual and perceived prevalence of crime, by municipality and crime type
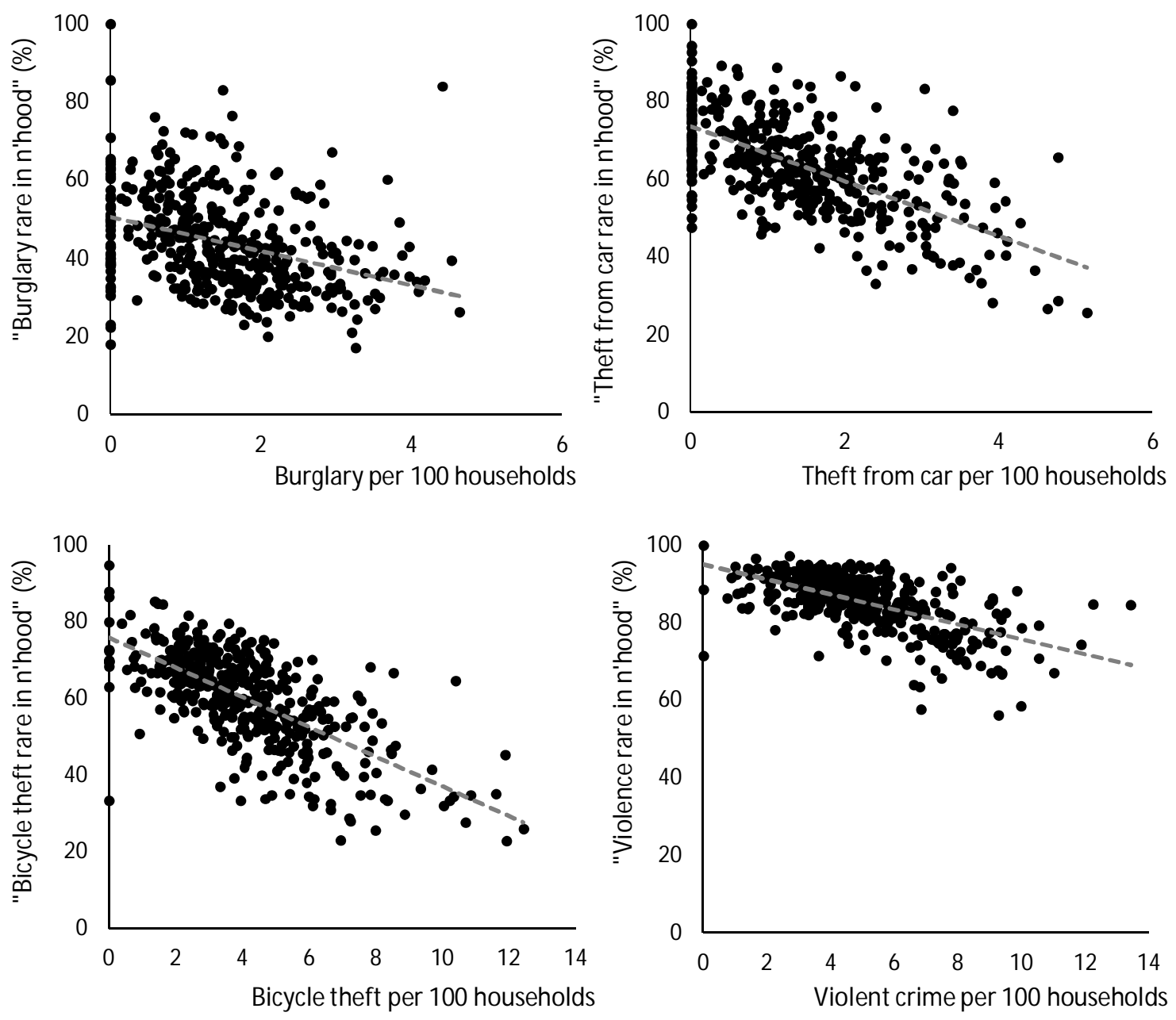
Figure 2. Perception of neighborhood risk and avoidance behavior in the neighborhood, individual cohort curves, relative to incumbent residents
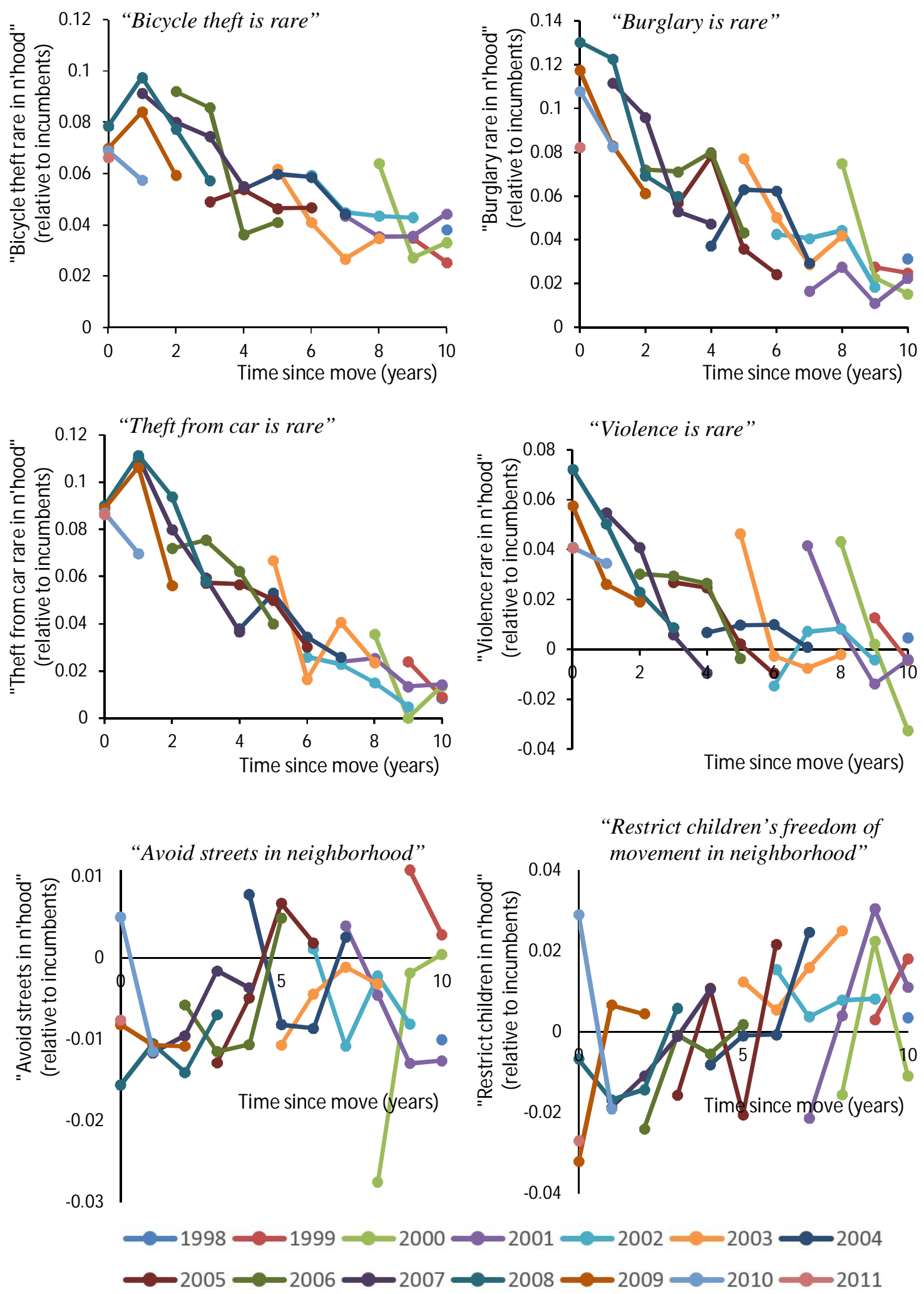

Note. Figures plot coefficients from Equation (5). Based on survey data for calendar years 2008-2011. 
Figure 3. Perception of neighborhood risk and avoidance behavior in the neighborhood, by type of move, relative to those who moved less than 1 year ago
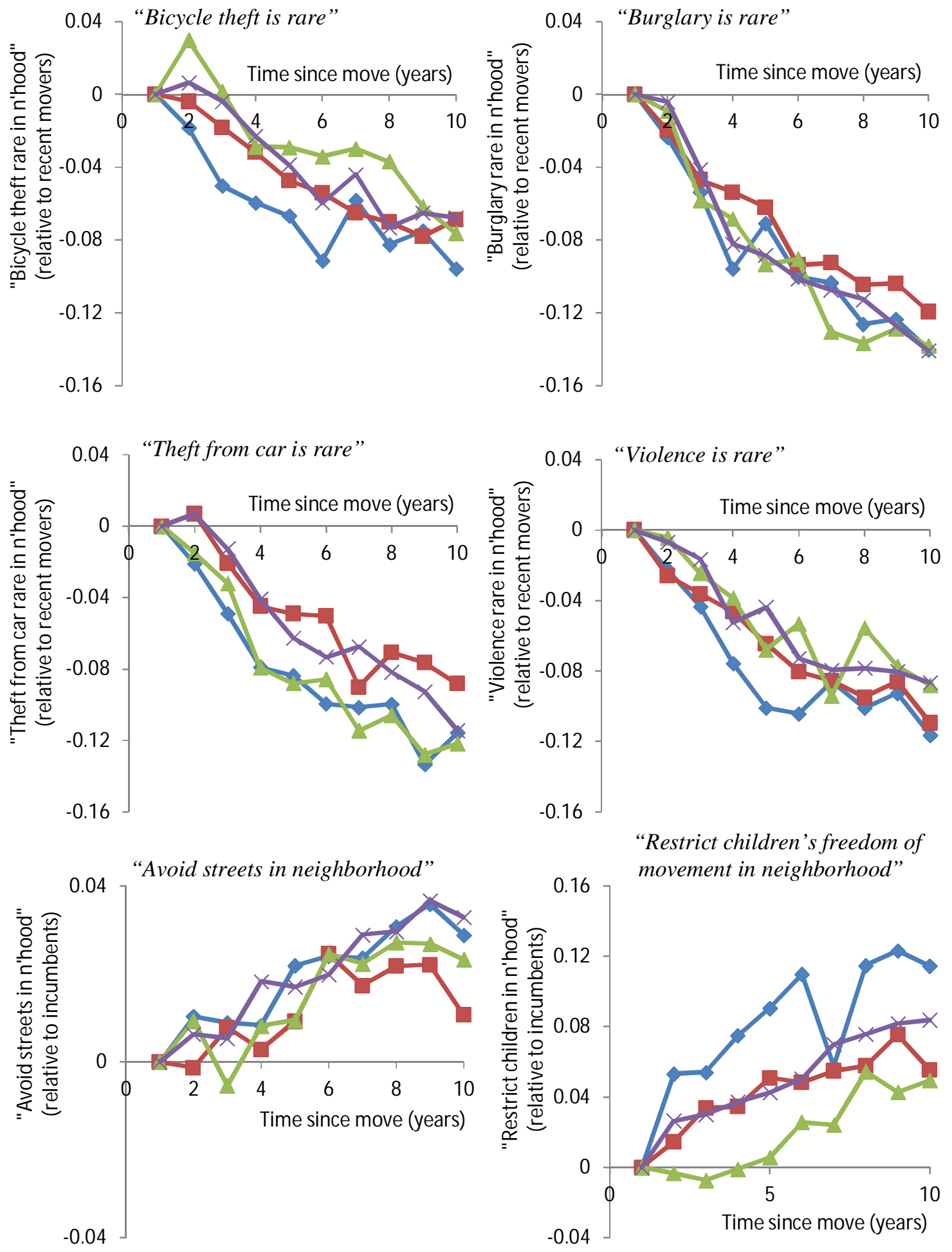

$\longrightarrow$ safe to risky $\rightleftharpoons$ risky to risky $\leadsto$ risky to safe to safe

Note. Safe neighborhoods have a rate of victimization of crime below the national average; risky neighborhoods have a rate of victimization of crime above the national average. 
Figure 4. Perception of risk of bicycle theft in the neighborhood since the move date relative to those who moved less than one year ago, by home owner/renter, age at time of move, educational attainment, gender, number of moves in last 10 years
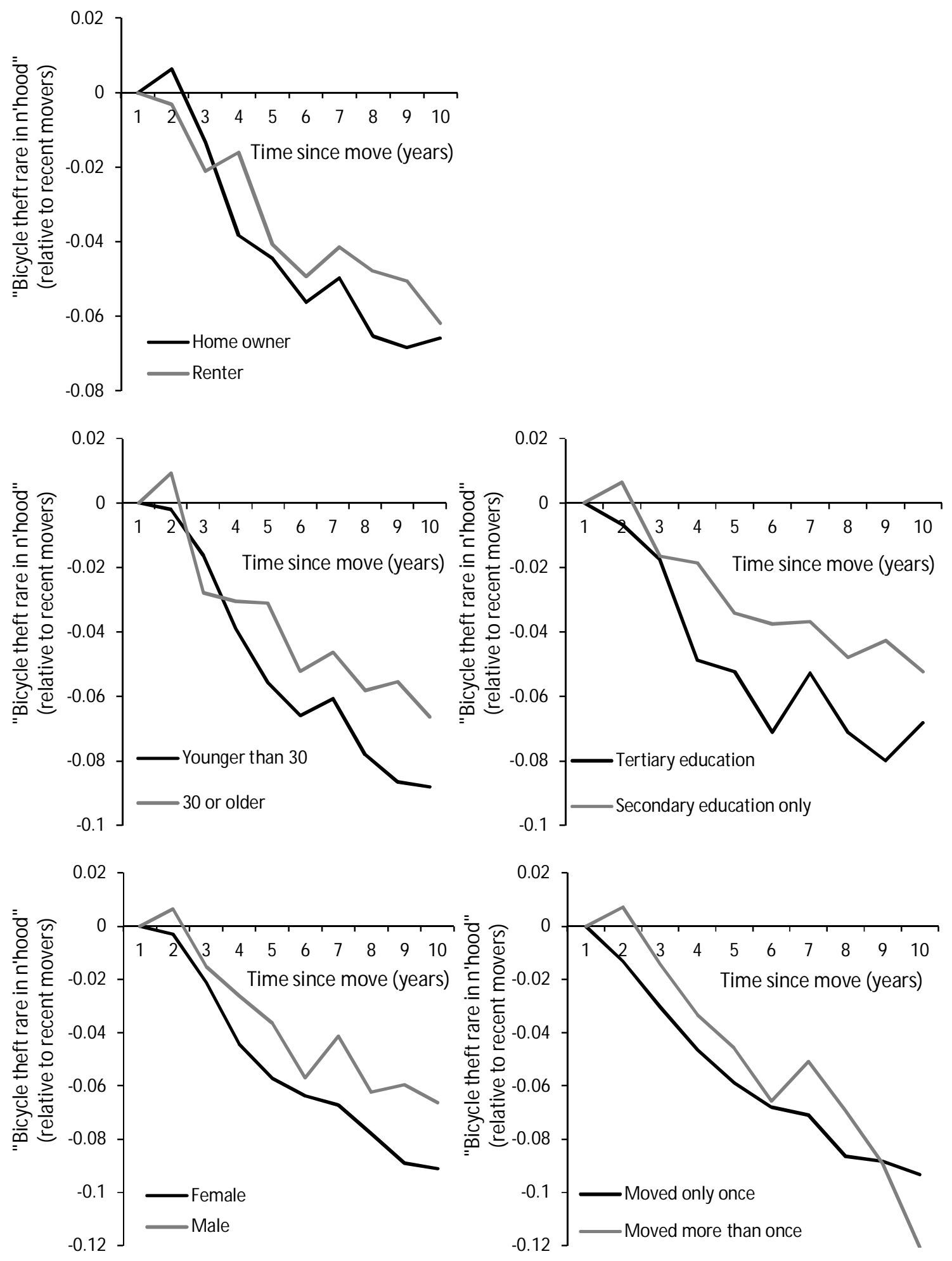
Figure 5 Perception of crime risk since the move date relative to those who moved less than one year ago, by distance of move and crime type
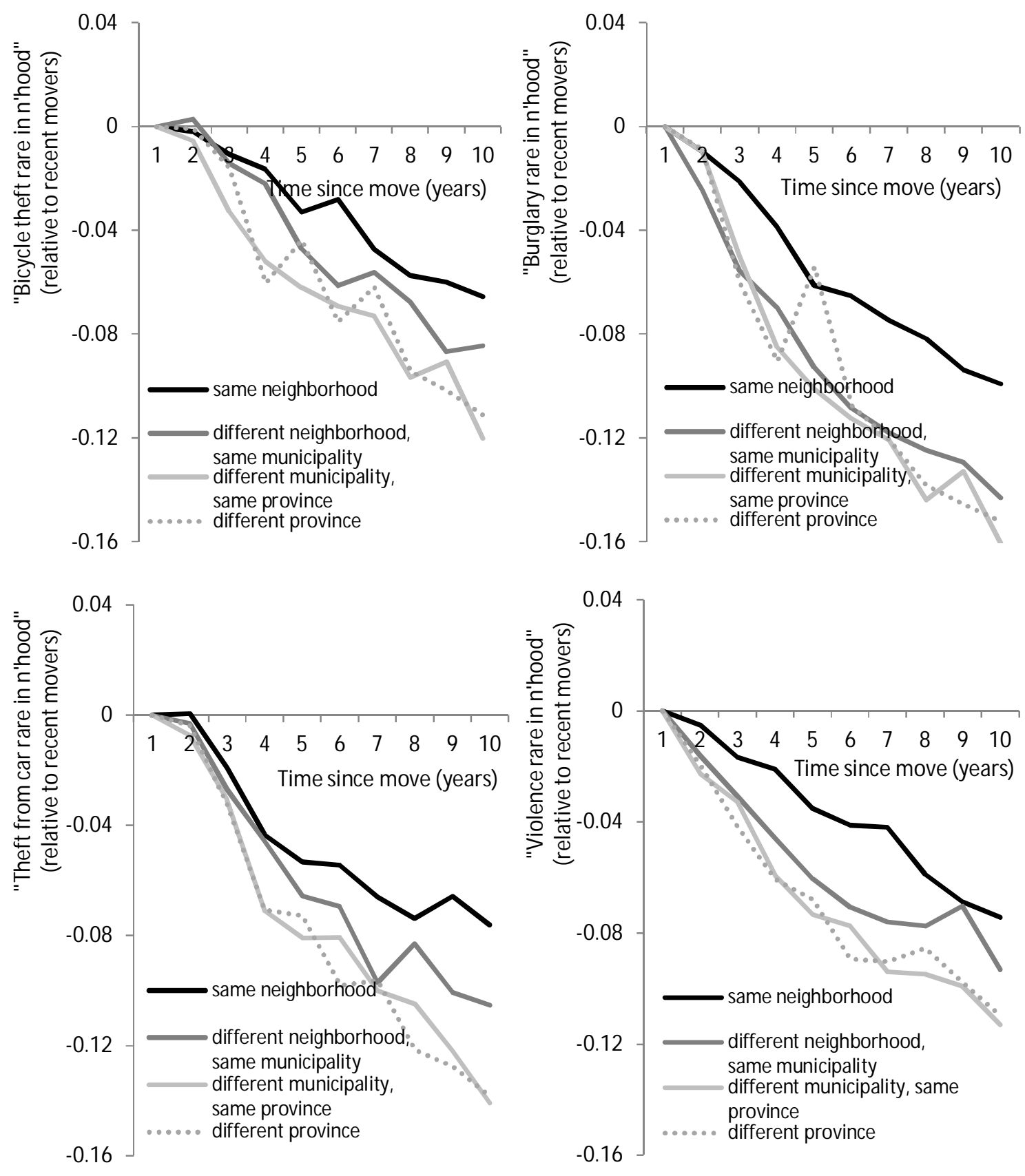
For online publication. Appendix tables. 
Table A1. Effect of time since the move date on risk perception and avoidance behavior, by level of crime in current and previous place of residence, time trends at national level

\begin{tabular}{|c|c|c|c|c|c|c|}
\hline & \multicolumn{2}{|c|}{$\begin{array}{l}\text { "Bicycle theft is rare in } \\
\text { neighborhood" }\end{array}$} & \multicolumn{2}{|c|}{$\begin{array}{l}\text { "Burglary is rare in } \\
\text { neighborhood" }\end{array}$} & \multicolumn{2}{|c|}{$\begin{array}{l}\text { "Theft from car is rare in } \\
\text { neighborhood" }\end{array}$} \\
\hline & $\begin{array}{l}\text { Without } \\
\text { cohort FE } \\
(1)\end{array}$ & $\begin{array}{c}\text { With } \\
\text { cohort FE } \\
(2)\end{array}$ & $\begin{array}{l}\text { Without } \\
\text { cohort FE } \\
\text { (3) }\end{array}$ & $\begin{array}{c}\text { With } \\
\text { cohort FE } \\
(4)\end{array}$ & $\begin{array}{l}\text { Without } \\
\text { cohort FE } \\
\text { (5) }\end{array}$ & $\begin{array}{c}\text { With } \\
\text { cohort FE } \\
(6)\end{array}$ \\
\hline $\begin{array}{l}\text { Months since move } x \\
\text { move from safe to } \\
\text { safe neighborhood }\end{array}$ & $\begin{array}{l}-0.6867 * * * \\
(0.0945)\end{array}$ & $\begin{array}{l}-0.8611 * * * \\
(0.2111)\end{array}$ & $\begin{array}{l}-0.8557 * * * \\
(0.0933)\end{array}$ & $\begin{array}{l}-1.4659 * * * \\
(0.2058)\end{array}$ & $\begin{array}{l}-1.0666 * * * \\
(0.0914)\end{array}$ & $\begin{array}{l}-1.4196 * * * \\
(0.2071)\end{array}$ \\
\hline $\begin{array}{l}\text { Months since move } x \\
\text { move from risky to } \\
\text { safe neighborhood }\end{array}$ & $\begin{array}{l}-0.7741 * * * \\
(0.1078)\end{array}$ & $\begin{array}{l}-0.9496 * * * \\
(0.2124)\end{array}$ & $\begin{array}{l}-0.8924 * * * \\
(0.1005)\end{array}$ & $\begin{array}{l}-1.5039 * * * \\
(0.2105)\end{array}$ & $\begin{array}{l}-1.0687 * * * \\
(0.1209)\end{array}$ & $\begin{array}{l}-1.4219 * * * \\
(0.2302)\end{array}$ \\
\hline $\begin{array}{l}\text { Months since move } x \\
\text { move from safe to } \\
\text { risky neighborhood }\end{array}$ & $\begin{array}{l}-0.3014 * * * \\
(0.1031)\end{array}$ & $\begin{array}{l}-0.4950 * * \\
(0.2150)\end{array}$ & $\begin{array}{l}-0.7271 * * * \\
(0.1233)\end{array}$ & $\begin{array}{l}-1.3271 * * * \\
(0.2245)\end{array}$ & $\begin{array}{l}-0.7369 * * * \\
(0.1158)\end{array}$ & $\begin{array}{l}-1.0815^{* * *} \\
(0.2176)\end{array}$ \\
\hline $\begin{array}{l}\text { Months since move } x \\
\text { move from risky to } \\
\text { risky neighborhood }\end{array}$ & $\begin{array}{l}-0.4442 * * * \\
(0.0824)\end{array}$ & $\begin{array}{l}-0.6388 * * * \\
(0.2013)\end{array}$ & $\begin{array}{l}-0.6183^{* * *} \\
(0.0959)\end{array}$ & $\begin{array}{l}-1.2229 * * * \\
(0.2104)\end{array}$ & $\begin{array}{l}-0.6671^{* * *} \\
(0.0898)\end{array}$ & $\begin{array}{l}-1.0160 * * * \\
(0.2070)\end{array}$ \\
\hline$p$-value cohort-FE $=0$ & & 0.3613 & & 0.0227 & & 0.4707 \\
\hline $\begin{array}{l}\text { Number of } \\
\text { observations }\end{array}$ & 425,593 & 425,593 & 447,487 & 447,487 & 428,190 & 428,190 \\
\hline R-Squared & 0.076 & 0.076 & 0.041 & 0.042 & 0.060 & 0.060 \\
\hline
\end{tabular}

Notes. Results show coefficients for linear regression as in Equation (2). Coefficients are multiplied by a factor of 1,000. A neighborhood is denoted as safe if the crime rate is below average. A neighborhood is denoted as risky if the crime rate is above average. Coefficients for age, age squared, female, household size, education, labor force participation, home ownership, two or more moves during last 10 years, type of residence, for moves from a risky to a safe municipality, for moves from a safe to a risky municipality, for moves from a risky to a risky municipality, survey mode, cohort fixed effects, and year fixed effects are not shown. Robust standard errors are given in parentheses. Statistical significance at *** $1 \% * * 5 \% * 10 \%$ level. 
Table A1. Effect of time since the move date on risk perception and avoidance behavior, by level of crime in current and previous place of residence, time trends at national level (continued)

\begin{tabular}{|c|c|c|c|c|c|c|}
\hline & \multicolumn{2}{|c|}{$\begin{array}{l}\text { "Violent crime is rare in } \\
\text { neighborhood" }\end{array}$} & \multicolumn{2}{|c|}{$\begin{array}{l}\text { "Frequently avoids } \\
\text { unsafe places in } \\
\text { neighborhood" }\end{array}$} & \multicolumn{2}{|c|}{$\begin{array}{l}\text { "Frequently doesn't allow } \\
\text { children to go to some } \\
\text { places in neighborhood" }\end{array}$} \\
\hline & $\begin{array}{l}\text { Without } \\
\text { cohort FE } \\
(7)\end{array}$ & $\begin{array}{c}\text { With } \\
\text { cohort FE } \\
\text { (8) }\end{array}$ & $\begin{array}{l}\text { Without } \\
\text { cohort FE } \\
\text { (9) }\end{array}$ & $\begin{array}{c}\text { With } \\
\text { cohort FE } \\
(10)\end{array}$ & $\begin{array}{l}\text { Without } \\
\text { cohort FE } \\
(11)\end{array}$ & $\begin{array}{c}\text { With } \\
\text { cohort FE } \\
(12)\end{array}$ \\
\hline $\begin{array}{l}\text { Months since move } x \\
\text { move from safe to } \\
\text { safe neighborhood }\end{array}$ & $\begin{array}{l}-0.5984^{* * *} \\
(0.0671)\end{array}$ & $\begin{array}{l}-1.2198 * * * \\
(0.1652)\end{array}$ & $\begin{array}{l}0.1726 * * * \\
(0.0395)\end{array}$ & $\begin{array}{l}0.3528 * * * \\
(0.0931)\end{array}$ & $\begin{array}{l}0.4294 * * * \\
(0.0734)\end{array}$ & $\begin{array}{l}0.8279 * * * \\
(0.1607)\end{array}$ \\
\hline $\begin{array}{l}\text { Months since move } x \\
\text { move from risky to } \\
\text { safe neighborhood }\end{array}$ & $\begin{array}{l}-0.5772 * * * \\
(0.0886)\end{array}$ & $\begin{array}{l}-1.1988 * * * \\
(0.1765)\end{array}$ & $\begin{array}{l}0.1266 * * * \\
(0.0427)\end{array}$ & $\begin{array}{l}0.3078 * * * \\
(0.0943)\end{array}$ & $\begin{array}{l}0.3635^{* * *} \\
(0.0810)\end{array}$ & $\begin{array}{l}0.7587^{* * *} \\
(0.1646)\end{array}$ \\
\hline $\begin{array}{l}\text { Months since move } x \\
\text { move from safe to } \\
\text { risky neighborhood }\end{array}$ & $\begin{array}{l}-0.5372 * * * \\
(0.1148)\end{array}$ & $\begin{array}{l}-1.1323 * * * \\
(0.1961)\end{array}$ & $\begin{array}{l}0.1050 * \\
(0.0602)\end{array}$ & $\begin{array}{l}0.2804 * * * \\
(0.0995)\end{array}$ & $\begin{array}{l}0.4736 * * * \\
(0.1246)\end{array}$ & $\begin{array}{l}0.8589 * * * \\
(0.1900)\end{array}$ \\
\hline $\begin{array}{l}\text { Months since move } x \\
\text { move from risky to } \\
\text { risky neighborhood }\end{array}$ & $\begin{array}{l}-0.5162 * * * \\
(0.0876)\end{array}$ & $\begin{array}{l}-1.1156 * * * \\
(0.1788)\end{array}$ & $\begin{array}{l}0.0280 \\
(0.0461)\end{array}$ & $\begin{array}{l}0.2048 * * \\
(0.0894)\end{array}$ & $\begin{array}{l}0.1875^{* *} \\
(0.0874)\end{array}$ & $\begin{array}{l}0.5734 * * * \\
(0.1623)\end{array}$ \\
\hline $\mathrm{p}$-value cohort-FE $=0$ & & 0.0111 & & 0.0479 & & 0.0923 \\
\hline $\begin{array}{l}\text { Number of } \\
\text { observations }\end{array}$ & 410,675 & 410,675 & 388,664 & 388,664 & 192,678 & 192,678 \\
\hline R-Squared & 0.073 & 0.073 & 0.027 & 0.027 & 0.035 & 0.038 \\
\hline
\end{tabular}

Notes. Results show coefficients for linear regression as in Equation (2). Coefficients are multiplied by a factor of 1,000. A neighborhood is denoted as safe if the crime rate is below average. A neighborhood is denoted as risky if the crime rate is above average. Coefficients for age, age squared, female, household size, education, labor force participation, home ownership, two or more moves during last 10 years, type of residence, for moves from a risky to a safe municipality, for moves from a safe to a risky municipality, for moves from a risky to a risky municipality, survey mode, cohort fixed effects, and year fixed effects are not shown. Robust standard errors are given in parentheses. Statistical significance at *** $1 \% * * 5 \% * 10 \%$ level. 
Table A2. Effect of time since the move date on risk perception and avoidance behavior, by level of crime in current and previous place of residence, time trends at municipality level

\begin{tabular}{|c|c|c|c|c|c|c|}
\hline & \multicolumn{2}{|c|}{$\begin{array}{l}\text { "Bicycle theft is rare in } \\
\text { neighborhood" }\end{array}$} & \multicolumn{2}{|c|}{$\begin{array}{l}\text { "Burglary is rare in } \\
\text { neighborhood" }\end{array}$} & \multicolumn{2}{|c|}{$\begin{array}{c}\text { "Theft from car is rare ir } \\
\text { neighborhood" }\end{array}$} \\
\hline & $\begin{array}{l}\text { Without } \\
\text { cohort FE } \\
\text { (1) }\end{array}$ & $\begin{array}{c}\text { With } \\
\text { cohort FE } \\
(2)\end{array}$ & $\begin{array}{c}\text { Without } \\
\text { cohort FE } \\
\text { (3) }\end{array}$ & $\begin{array}{c}\text { With } \\
\text { cohort FE } \\
(4)\end{array}$ & $\begin{array}{c}\text { Without } \\
\text { cohort FE } \\
\text { (5) }\end{array}$ & $\begin{array}{c}\text { With } \\
\text { cohort FE } \\
(6)\end{array}$ \\
\hline $\begin{array}{l}\text { Months since move } x \\
\text { move from safe to } \\
\text { safe neighborhood }\end{array}$ & $\begin{array}{l}-0.5219 * * * \\
(0.1017)\end{array}$ & $\begin{array}{l}-0.8541 * * * \\
(0.1983)\end{array}$ & $\begin{array}{l}-0.8286^{* * *} \\
(0.0908)\end{array}$ & $\begin{array}{l}-1.4100 * * * \\
(0.1843)\end{array}$ & $\begin{array}{l}-0.9657 * * * \\
(0.0878)\end{array}$ & $\begin{array}{l}-1.3837 * * * \\
(0.1960)\end{array}$ \\
\hline $\begin{array}{l}\text { Months since move } x \\
\text { move from risky to } \\
\text { safe neighborhood }\end{array}$ & $\begin{array}{l}-0.6354 * * * \\
(0.1012)\end{array}$ & $\begin{array}{l}-0.9698 * * * \\
(0.1761)\end{array}$ & $\begin{array}{l}-0.8696 * * * \\
(0.1042)\end{array}$ & $\begin{array}{l}-1.4521 * * * \\
(0.2022)\end{array}$ & $\begin{array}{l}-0.9964 * * * \\
(0.1309)\end{array}$ & $\begin{array}{l}-1.4148 * * * \\
(0.1972)\end{array}$ \\
\hline $\begin{array}{l}\text { Months since move } x \\
\text { move from safe to } \\
\text { risky neighborhood }\end{array}$ & $\begin{array}{l}-0.2475^{* *} \\
(0.1123)\end{array}$ & $\begin{array}{l}-0.6082 * * * \\
(0.2093)\end{array}$ & $\begin{array}{l}-0.6686 * * * \\
(0.1387)\end{array}$ & $\begin{array}{l}-1.2470 * * * \\
(0.2092)\end{array}$ & $\begin{array}{l}-0.6952 * * * \\
(0.1179)\end{array}$ & $\begin{array}{l}-1.1176 * * * \\
(0.1899)\end{array}$ \\
\hline $\begin{array}{l}\text { Months since move } x \\
\text { move from risky to } \\
\text { risky neighborhood }\end{array}$ & $\begin{array}{l}-0.3489 * * * \\
(0.0568)\end{array}$ & $\begin{array}{l}-0.7104 * * * \\
(0.1873)\end{array}$ & $\begin{array}{l}-0.5960 * * * \\
(0.1002)\end{array}$ & $\begin{array}{l}-1.1772 * * * \\
(0.2074)\end{array}$ & $\begin{array}{l}-0.6327^{* * *} \\
(0.0696)\end{array}$ & $\begin{array}{l}-1.0588 * * * \\
(0.1970)\end{array}$ \\
\hline$p$-value cohort-FE $=0$ & & 0.0004 & & 0.0168 & & 0.0222 \\
\hline $\begin{array}{l}\text { Number of } \\
\text { observations }\end{array}$ & 426,499 & 426,499 & 448,376 & 448,376 & 429,058 & 429,058 \\
\hline R-Squared & 0.029 & 0.029 & 0.042 & 0.043 & 0.026 & 0.026 \\
\hline
\end{tabular}

Notes. Results show coefficients for linear regression as in Equation (2). Coefficients are multiplied by a factor of 1,000. A neighborhood is denoted as safe if the crime rate is below average. A neighborhood is denoted as risky if the crime rate is above average. Coefficients for age, age squared, female, household size, education, labor force participation, home ownership, two or more moves during last 10 years, type of residence, for moves from a risky to a safe municipality, for moves from a safe to a risky municipality, for moves from a risky to a risky municipality, survey mode, cohort fixed effects, and fixed effects for municipality and year interactions are not shown. Robust standard errors (clustered at municipality level) are given in parentheses. Statistical significance at $* * * 1 \% * * 5 \% *$ $10 \%$ level. 
Table A2. Effect of time since the move date on risk perception and avoidance behavior, by level of crime in current and previous place of residence, time trends at municipality level (continued)

\begin{tabular}{|c|c|c|c|c|c|c|}
\hline & \multicolumn{2}{|c|}{$\begin{array}{l}\text { "Violent crime is rare in } \\
\text { neighborhood" }\end{array}$} & \multicolumn{2}{|c|}{$\begin{array}{l}\text { "Frequently avoids } \\
\text { unsafe places in } \\
\text { neighborhood" }\end{array}$} & \multicolumn{2}{|c|}{$\begin{array}{l}\text { "Frequently doesn't allow } \\
\text { children to go to some } \\
\text { places in neighborhood" }\end{array}$} \\
\hline & $\begin{array}{l}\text { Without } \\
\text { cohort FE } \\
(7)\end{array}$ & $\begin{array}{c}\text { With } \\
\text { cohort FE } \\
(8)\end{array}$ & $\begin{array}{l}\text { Without } \\
\text { cohort FE } \\
(9)\end{array}$ & $\begin{array}{c}\text { With } \\
\text { cohort FE } \\
(10)\end{array}$ & $\begin{array}{l}\text { Without } \\
\text { cohort FE } \\
(11)\end{array}$ & $\begin{array}{c}\text { With } \\
\text { cohort FE } \\
(12)\end{array}$ \\
\hline $\begin{array}{l}\text { Months since move } x \\
\text { move from safe to } \\
\text { safe neighborhood }\end{array}$ & $\begin{array}{l}-0.4689 * * * \\
(0.0638)\end{array}$ & $\begin{array}{l}-1.0201 * * * \\
(0.1572)\end{array}$ & $\begin{array}{l}0.1382 * * * \\
(0.0407)\end{array}$ & $\begin{array}{l}0.2723 * * * \\
(0.0940)\end{array}$ & $\begin{array}{l}0.3923 * * * \\
(0.0660)\end{array}$ & $\begin{array}{l}0.8022 * * * \\
(0.1716)\end{array}$ \\
\hline $\begin{array}{l}\text { Months since move } x \\
\text { move from risky to } \\
\text { safe neighborhood }\end{array}$ & $\begin{array}{l}-0.4615^{* * *} \\
(0.1072)\end{array}$ & $\begin{array}{l}-1.0126 * * * \\
(0.1872)\end{array}$ & $\begin{array}{l}0.1023^{* *} \\
(0.0460)\end{array}$ & $\begin{array}{l}0.2369 * * * \\
(0.0812)\end{array}$ & $\begin{array}{l}0.3530 * * * \\
(0.0832)\end{array}$ & $\begin{array}{l}0.7580 * * * \\
(0.1540)\end{array}$ \\
\hline $\begin{array}{l}\text { Months since move } x \\
\text { move from safe to } \\
\text { risky neighborhood }\end{array}$ & $\begin{array}{l}-0.4540 * * * \\
(0.1031)\end{array}$ & $\begin{array}{l}-0.9835^{* * *} \\
(0.1693)\end{array}$ & $\begin{array}{l}0.0869 \\
(0.0563)\end{array}$ & $\begin{array}{l}0.2161^{* *} \\
(0.0994)\end{array}$ & $\begin{array}{l}0.4488 * * * \\
(0.1303)\end{array}$ & $\begin{array}{l}0.8461 * * * \\
(0.2160)\end{array}$ \\
\hline $\begin{array}{l}\text { Months since move } x \\
\text { move from risky to } \\
\text { risky neighborhood }\end{array}$ & $\begin{array}{l}-0.4434 * * * \\
(0.0935)\end{array}$ & $\begin{array}{l}-0.9755^{* * *} \\
(0.1717)\end{array}$ & $\begin{array}{l}0.0084 \\
(0.0557)\end{array}$ & $\begin{array}{l}0.1382 \\
(0.1026)\end{array}$ & $\begin{array}{l}0.1567^{*} \\
(0.0810)\end{array}$ & $\begin{array}{l}0.5536 * * * \\
(0.0801)\end{array}$ \\
\hline$p$-value cohort-FE $=0$ & & 0.0290 & & 0.0083 & & 0.0393 \\
\hline $\begin{array}{l}\text { Number of } \\
\text { observations }\end{array}$ & 411,499 & 411,499 & 389,373 & 389,374 & 192,978 & 192,978 \\
\hline R-Squared & 0.034 & 0.034 & 0.020 & 0.020 & 0.024 & 0.024 \\
\hline
\end{tabular}

Notes. Results show coefficients for linear regression as in Equation (2). Coefficients are multiplied by a factor of 1,000. A neighborhood is denoted as safe if the crime rate is below average. A neighborhood is denoted as risky if the crime rate is above average. Coefficients for age, age squared, female, household size, education, labor force participation, home ownership, two or more moves during last 10 years, type of residence, for moves from a risky to a safe municipality, for moves from a safe to a risky municipality, for moves from a risky to a risky municipality, survey mode, cohort fixed effects, and fixed effects for municipality and year interactions are not shown. Robust standard errors (clustered at municipality level) are given in parentheses. Statistical significance at $* * * 1 \% * * 5 \% *$ $10 \%$ level. 
Table A3. Effect of time since the move date on risk perception and avoidance behavior, by level of crime in current and previous place of residence, ordered logit regressions

\begin{tabular}{|c|c|c|c|c|c|c|}
\hline & \multicolumn{2}{|c|}{$\begin{array}{l}\text { "Bicycle theft is rare in } \\
\text { neighborhood" }\end{array}$} & \multicolumn{2}{|c|}{$\begin{array}{l}\text { "Burglary is rare in } \\
\text { neighborhood" }\end{array}$} & \multicolumn{2}{|c|}{$\begin{array}{l}\text { "Theft from car is rare in } \\
\text { neighborhood" }\end{array}$} \\
\hline & $\begin{array}{l}\text { Without } \\
\text { cohort FE } \\
\text { (1) }\end{array}$ & $\begin{array}{c}\text { With } \\
\text { cohort FE } \\
(2)\end{array}$ & $\begin{array}{c}\text { Without } \\
\text { cohort FE } \\
\text { (3) }\end{array}$ & $\begin{array}{c}\text { With } \\
\text { cohort FE } \\
\text { (4) }\end{array}$ & $\begin{array}{l}\text { Without } \\
\text { cohort FE } \\
\text { (5) }\end{array}$ & $\begin{array}{c}\text { With } \\
\text { cohort FE } \\
\text { (6) }\end{array}$ \\
\hline $\begin{array}{l}\text { Months since move } x \\
\text { move from safe to } \\
\text { safe neighborhood }\end{array}$ & $\begin{array}{l}-3.3164 * * * \\
(0.4309)\end{array}$ & $\begin{array}{l}-5.0376 * * * \\
(0.9251)\end{array}$ & $\begin{array}{l}-3.4189 * * * \\
(0.3916)\end{array}$ & $\begin{array}{l}-6.7704 * * * \\
(0.8918)\end{array}$ & $\begin{array}{l}-4.9868 * * * \\
(0.4272)\end{array}$ & $\begin{array}{l}-6.9196 * * * \\
(0.9477)\end{array}$ \\
\hline $\begin{array}{l}\text { Months since move } x \\
\text { move from risky to } \\
\text { safe neighborhood }\end{array}$ & $\begin{array}{l}-3.3499 * * * \\
(0.4621)\end{array}$ & $\begin{array}{l}-5.0678 * * * \\
(0.9077)\end{array}$ & $\begin{array}{l}-3.4952 * * * \\
(0.4156)\end{array}$ & $\begin{array}{l}-6.8484 * * * \\
(0.9173)\end{array}$ & $\begin{array}{l}-4.7069 * * * \\
(0.5217)\end{array}$ & $\begin{array}{l}-6.6396 * * * \\
(1.0155)\end{array}$ \\
\hline $\begin{array}{l}\text { Months since move } x \\
\text { move from safe to } \\
\text { risky neighborhood }\end{array}$ & $\begin{array}{l}-0.5120 \\
(0.4706)\end{array}$ & $\begin{array}{l}-2.3578 * * \\
(0.9515)\end{array}$ & $\begin{array}{l}-2.9154 * * * \\
(0.5230)\end{array}$ & $\begin{array}{l}-6.2134 * * * \\
(0.9853)\end{array}$ & $\begin{array}{l}-2.7883^{* * *} \\
(0.4757)\end{array}$ & $\begin{array}{l}-4.6752 * * * \\
(0.9488)\end{array}$ \\
\hline $\begin{array}{l}\text { Months since move } x \\
\text { move from risky to } \\
\text { risky neighborhood }\end{array}$ & $\begin{array}{l}-1.4584 * * * \\
(0.3692)\end{array}$ & $\begin{array}{l}-3.3054 * * * \\
(0.8849)\end{array}$ & $\begin{array}{l}-2.7133 * * * \\
(0.4583)\end{array}$ & $\begin{array}{l}-6.0332 * * * \\
(0.9576)\end{array}$ & $\begin{array}{l}-2.7428 * * * \\
(0.4131)\end{array}$ & $\begin{array}{l}-4.6497 * * * \\
(0.9367)\end{array}$ \\
\hline$p$-value cohort-FE $=0$ & & 0.0463 & & 0,0114 & & 0.3332 \\
\hline $\begin{array}{l}\text { Number of } \\
\text { observations }\end{array}$ & 425,593 & 425,593 & 447,487 & 447,487 & 428,190 & 428,190 \\
\hline Pseudo R-Squared & 0.0481 & 0.0481 & 0.0185 & 0.0186 & 0.0384 & 0.0384 \\
\hline
\end{tabular}

Notes. Results show coefficients for ordered logit regression. Coefficients are multiplied by a factor of 1,000. A neighborhood is denoted as safe if the crime rate is below average. A neighborhood is denoted as risky if the crime rate is above average. Coefficients for age, age squared, female, household size, education, labor force participation, home ownership, two or more moves during last 10 years, type of residence, for moves from a risky to a safe municipality, for moves from a safe to a risky municipality, for moves from a risky to a risky municipality, survey mode, cohort fixed effects, and year fixed effects are not shown. Robust standard errors are given in parentheses. Statistical significance at *** $1 \% * * 5 \% * 10 \%$ level. 
Table A3. Effect of time since the move date on risk perception and avoidance behavior, by level of crime in current and previous place of residence, ordered logit regressions (continued)

\begin{tabular}{|c|c|c|c|c|c|c|}
\hline & \multicolumn{2}{|c|}{$\begin{array}{l}\text { "Violent crime is rare in } \\
\text { neighborhood" }\end{array}$} & \multicolumn{2}{|c|}{$\begin{array}{l}\text { "Frequently avoids } \\
\text { unsafe places in } \\
\text { neighborhood" }\end{array}$} & \multicolumn{2}{|c|}{$\begin{array}{l}\text { "Frequently doesn't allow } \\
\text { children to go to some } \\
\text { places in neighborhood" }\end{array}$} \\
\hline & $\begin{array}{l}\text { Without } \\
\text { cohort FE } \\
(7)\end{array}$ & $\begin{array}{c}\text { With } \\
\text { cohort FE } \\
\text { (8) }\end{array}$ & $\begin{array}{l}\text { Without } \\
\text { cohort FE } \\
\text { (9) }\end{array}$ & $\begin{array}{c}\text { With } \\
\text { cohort FE } \\
(10)\end{array}$ & $\begin{array}{l}\text { Without } \\
\text { cohort FE } \\
(11)\end{array}$ & $\begin{array}{c}\text { With } \\
\text { cohort FE } \\
(12)\end{array}$ \\
\hline $\begin{array}{l}\text { Months since move } x \\
\text { move from safe to } \\
\text { safe neighborhood }\end{array}$ & $\begin{array}{l}-4.0211^{* * *} \\
(0.5758)\end{array}$ & $\begin{array}{l}-7.7088 * * * \\
(1.1150)\end{array}$ & $\begin{array}{l}-3.5050 * * * \\
(0.5522)\end{array}$ & $\begin{array}{l}-4.6187 * * * \\
(1.0360)\end{array}$ & $\begin{array}{l}-3.9973 * * * \\
(0.5747)\end{array}$ & $\begin{array}{l}-5.6213^{* * *} \\
(1.1461)\end{array}$ \\
\hline $\begin{array}{l}\text { Months since move } x \\
\text { move from risky to } \\
\text { safe neighborhood }\end{array}$ & $\begin{array}{l}-3.5814 * * * \\
(0.7199)\end{array}$ & $\begin{array}{l}-7.2709 * * * \\
(1.2074)\end{array}$ & $\begin{array}{l}-2.2159 * * * \\
(0.5731)\end{array}$ & $\begin{array}{l}-3.3441 * * * \\
(1.0632)\end{array}$ & $\begin{array}{l}-4.5403 * * * \\
(0.5987)\end{array}$ & $\begin{array}{l}-6.1642 * * * \\
(1.1818)\end{array}$ \\
\hline $\begin{array}{l}\text { Months since move } x \\
\text { move from safe to } \\
\text { risky neighborhood }\end{array}$ & $\begin{array}{l}-3.4460 * * * \\
(0.5690)\end{array}$ & $\begin{array}{l}-6.9616 * * * \\
(1.1554)\end{array}$ & $\begin{array}{l}-2.9913 * * * \\
(0.5474)\end{array}$ & $\begin{array}{l}-4.1057 * * * \\
(0.9791)\end{array}$ & $\begin{array}{l}-3.8578 * * * \\
(0.7422)\end{array}$ & $\begin{array}{l}-5.4578 * * * \\
(1.2022)\end{array}$ \\
\hline $\begin{array}{l}\text { Months since move } x \\
\text { move from risky to } \\
\text { risky neighborhood }\end{array}$ & $\begin{array}{l}-3.2089 * * * \\
(0.4060)\end{array}$ & $\begin{array}{l}-6.7671 * * * \\
(1.0654)\end{array}$ & $\begin{array}{l}-1.601 * * * \\
(0.4272)\end{array}$ & $\begin{array}{l}-2.8123 * * * \\
(0.9625)\end{array}$ & $\begin{array}{l}-3.1107 * * * \\
(0.5040)\end{array}$ & $\begin{array}{l}-4.7046 * * * \\
(1.1140)\end{array}$ \\
\hline$p$-value cohort-FE $=0$ & & 0.0141 & & 0.2068 & & 0.1357 \\
\hline $\begin{array}{l}\text { Number of } \\
\text { observations }\end{array}$ & 410,675 & 410,675 & 388,664 & 388,664 & 192,678 & 192,678 \\
\hline R-Squared & 0.0626 & 0.0627 & 0.0530 & 0.0531 & 0.0439 & 0.0439 \\
\hline
\end{tabular}

Notes. Results show coefficients for ordered logit regression. Coefficients are multiplied by a factor of 1,000. A neighborhood is denoted as safe if the crime rate is below average. A neighborhood is denoted as risky if the crime rate is above average. Coefficients for age, age squared, female, household size, education, labor force participation, home ownership, two or more moves during last 10 years, type of residence, for moves from a risky to a safe municipality, for moves from a safe to a risky municipality, for moves from a risky to a risky municipality, survey mode, cohort fixed effects, and year fixed effects are not shown. Robust standard errors are given in parentheses. Statistical significance at $* * * 1 \% * * 5 \% * 10 \%$ level. 
Table A4. Effect of time since the move date on risk perception and avoidance behavior, by level of crime in current and previous place of residence, Heckman selection model for "don't know" answers

\begin{tabular}{|c|c|c|c|c|c|c|}
\hline & \multicolumn{2}{|c|}{$\begin{array}{l}\text { "Bicycle theft is rare in } \\
\text { neighborhood" }\end{array}$} & \multicolumn{2}{|c|}{$\begin{array}{l}\text { "Burglary is rare in } \\
\text { neighborhood" }\end{array}$} & \multicolumn{2}{|c|}{$\begin{array}{l}\text { "Theft from car is rare in } \\
\text { neighborhood" }\end{array}$} \\
\hline & $\begin{array}{l}1^{\text {st }} \text { stage } \\
\text { estimation } \\
(1)\end{array}$ & $\begin{array}{l}2^{\text {nd }} \text { stage } \\
\text { estimation } \\
(2)\end{array}$ & $\begin{array}{c}1^{\text {st }} \text { stage } \\
\text { estimation } \\
(3)\end{array}$ & $\begin{array}{l}2^{\text {nd }} \text { stage } \\
\text { estimation } \\
(4)\end{array}$ & $\begin{array}{c}1^{\text {st }} \text { stage } \\
\text { estimation } \\
(5)\end{array}$ & $\begin{array}{c}2^{\text {nd }} \text { stage } \\
\text { estimation } \\
\text { (6) }\end{array}$ \\
\hline $\begin{array}{l}\text { Months since move } x \\
\text { move from safe to } \\
\text { safe neighborhood }\end{array}$ & $\begin{array}{l}5.3552 * * * \\
(0.3933)\end{array}$ & $\begin{array}{l}-0.8227 * * * \\
(0.1530)\end{array}$ & $\begin{array}{l}5.3792 * * * \\
(0.4228)\end{array}$ & $\begin{array}{l}-1.3734 * * * \\
(0.1472)\end{array}$ & $\begin{array}{l}5.3111 * * * \\
(0.4041)\end{array}$ & $\begin{array}{l}-1.2645^{* * *} \\
(0.1521)\end{array}$ \\
\hline $\begin{array}{l}\text { Months since move } x \\
\text { move from risky to } \\
\text { safe neighborhood }\end{array}$ & $\begin{array}{l}5.1507 * * * \\
(0.4075)\end{array}$ & $\begin{array}{l}-0.8800 * * * \\
(0.1593)\end{array}$ & $\begin{array}{l}5.3078 * * * \\
(0.4371)\end{array}$ & $\begin{array}{l}-1.3953 * * * \\
(0.1536)\end{array}$ & $\begin{array}{l}5.2026 * * * \\
(0.4186)\end{array}$ & $\begin{array}{l}-1.2483 * * * \\
(0.1586)\end{array}$ \\
\hline $\begin{array}{l}\text { Months since move } x \\
\text { move from safe to } \\
\text { risky neighborhood }\end{array}$ & $\begin{array}{l}4.0142 * * * \\
(0.4131)\end{array}$ & $\begin{array}{l}-0.4629 * * * \\
(0.1618)\end{array}$ & $\begin{array}{l}5.1211 * * * \\
(0.4361)\end{array}$ & $\begin{array}{l}-1.2280 * * * \\
(0.1600)\end{array}$ & $\begin{array}{l}5.0893 * * * \\
(0.4219)\end{array}$ & $\begin{array}{l}-0.9152 * * * \\
(0.1639)\end{array}$ \\
\hline $\begin{array}{l}\text { Months since move } x \\
\text { move from risky to } \\
\text { risky neighborhood }\end{array}$ & $\begin{array}{l}3.8414 * * * \\
(0.3738)\end{array}$ & $\begin{array}{l}-0.6205^{* * *} \\
(0.1457)\end{array}$ & $\begin{array}{l}5.1106 * * * \\
(0.3959)\end{array}$ & $\begin{array}{l}-1.1216 * * * \\
(0.1442)\end{array}$ & $\begin{array}{l}4.7428 * * * \\
(0.3820)\end{array}$ & $\begin{array}{l}-0.8702 * * * \\
(0.1473)\end{array}$ \\
\hline $\begin{array}{l}\text { "Don't know" answer } \\
\text { about availability of } \\
\text { playgrounds }\end{array}$ & $\begin{array}{l}-0.4047 * * * \\
(0.0073)\end{array}$ & & $\begin{array}{l}-0.3820 * * * \\
(0.0078)\end{array}$ & & $\begin{array}{l}-0.4037 * * * \\
(0.0074)\end{array}$ & \\
\hline $\begin{array}{l}\text { Number of } \\
\text { observations }\end{array}$ & 526,740 & 526,740 & 526,668 & 526,668 & 526,137 & 526,137 \\
\hline
\end{tabular}

Notes. Results show coefficients for Heckman selection model. Coefficients for months since the move date are multiplied by a factor of 1,000. A neighborhood is denoted as safe if the crime rate is below average. A neighborhood is denoted as risky if the crime rate is above average. Coefficients for age, age squared, female, household size, education, labor force participation, home ownership, two or more moves during last 10 years, type of residence, for moves from a risky to a safe municipality, for moves from a safe to a risky municipality, for moves from a risky to a risky municipality, survey mode, cohort fixed effects, and year fixed effects are not shown. Robust standard errors are given in parentheses. Statistical significance at *** 1\%** 5\%* $10 \%$ level. 
Table A4. Effect of time since the move date on risk perception and avoidance behavior, by level of crime in current and previous place of residence, Heckman selection model for "don't know" answers (continued)

\begin{tabular}{|c|c|c|c|c|c|c|}
\hline & \multicolumn{2}{|c|}{$\begin{array}{l}\text { "Violent crime is rare in } \\
\text { neighborhood" }\end{array}$} & \multicolumn{2}{|c|}{$\begin{array}{l}\text { "Frequently avoids } \\
\text { unsafe places in } \\
\text { neighborhood" }\end{array}$} & \multicolumn{2}{|c|}{$\begin{array}{l}\text { "Frequently doesn't allow } \\
\text { children to go to some } \\
\text { places in neighborhood" }\end{array}$} \\
\hline & $\begin{array}{l}1^{\text {st }} \text { stage } \\
\text { estimation } \\
(7)\end{array}$ & $\begin{array}{l}2^{\text {nd }} \text { stage } \\
\text { estimation } \\
\text { (8) }\end{array}$ & $\begin{array}{l}1^{\text {st }} \text { stage } \\
\text { estimation } \\
(9)\end{array}$ & $\begin{array}{l}2^{\text {nd }} \text { stage } \\
\text { estimation } \\
(10)\end{array}$ & $\begin{array}{l}1^{\text {st }} \text { stage } \\
\text { estimation } \\
(11)\end{array}$ & $\begin{array}{c}2^{\text {nd }} \text { stage } \\
\text { estimation } \\
(12)\end{array}$ \\
\hline $\begin{array}{l}\text { Months since move } x \\
\text { move from safe to } \\
\text { safe neighborhood }\end{array}$ & $\begin{array}{l}3.3967 * * * \\
(0.3957)\end{array}$ & $\begin{array}{l}-1.2729 * * * \\
(0.1232)\end{array}$ & $\begin{array}{l}0.6683 \\
(0.7944)\end{array}$ & $\begin{array}{l}0.3484 * * * \\
(0.0719)\end{array}$ & $\begin{array}{l}2.9217 * * * \\
(0.7137)\end{array}$ & $\begin{array}{l}0.9018 * * * \\
(0.1337)\end{array}$ \\
\hline $\begin{array}{l}\text { Months since move } x \\
\text { move from risky to } \\
\text { safe neighborhood }\end{array}$ & $\begin{array}{l}3.3815^{* * *} \\
(0.4102)\end{array}$ & $\begin{array}{l}-1.2326 * * * \\
(0.1284)\end{array}$ & $\begin{array}{l}1.4212^{*} \\
(0.8363)\end{array}$ & $\begin{array}{l}0.3057 * * * \\
(0.0748)\end{array}$ & $\begin{array}{l}3.0410 * * * \\
(0.7537)\end{array}$ & $\begin{array}{l}0.8351 * * * \\
(0.1389)\end{array}$ \\
\hline $\begin{array}{l}\text { Months since move } x \\
\text { move from safe to } \\
\text { risky neighborhood }\end{array}$ & $\begin{array}{l}3.3085^{* * *} \\
(0.4125)\end{array}$ & $\begin{array}{l}-1.1922 * * * \\
(0.1331)\end{array}$ & $\begin{array}{l}-0.1047 \\
(0.8568)\end{array}$ & $\begin{array}{l}0.2735^{* * *} \\
(0.0763)\end{array}$ & $\begin{array}{l}3.0627 * * * \\
(0.7873)\end{array}$ & $\begin{array}{l}0.9391 * * * \\
(0.1480)\end{array}$ \\
\hline $\begin{array}{l}\text { Months since move } x \\
\text { move from risky to } \\
\text { risky neighborhood }\end{array}$ & $\begin{array}{l}3.4763 * * * \\
(0.3731)\end{array}$ & $\begin{array}{l}-1.1811^{* * *} \\
(0.1199)\end{array}$ & $\begin{array}{l}0.9064 \\
(0.7729)\end{array}$ & $\begin{array}{l}0.2075^{* * *} \\
(0.0691)\end{array}$ & $\begin{array}{l}3.4001 * * * \\
(0.7112)\end{array}$ & $\begin{array}{l}0.6517 * * * \\
(0.1313)\end{array}$ \\
\hline $\begin{array}{l}\text { "Don't know" answer } \\
\text { about availability of } \\
\text { playgrounds }\end{array}$ & $\begin{array}{l}-0.3721 * * * \\
(0.0074)\end{array}$ & & $\begin{array}{l}-0.1964 * * * \\
(0.0143)\end{array}$ & & $\begin{array}{l}-0.5541 * * * \\
(0.0172)\end{array}$ & \\
\hline $\begin{array}{l}\text { Number of } \\
\text { observations }\end{array}$ & 526,486 & 526,486 & 402,242 & 402,242 & 225,078 & 225,078 \\
\hline
\end{tabular}

Notes. Results show coefficients for Heckman selection model. Coefficients for months since the move date are multiplied by a factor of 1,000. A neighborhood is denoted as safe if the crime rate is below average. A neighborhood is denoted as risky if the crime rate is above average. Coefficients for age, age squared, female, household size, education, labor force participation, home ownership, two or more moves during last 10 years, type of residence, for moves from a risky to a safe municipality, for moves from a safe to a risky municipality, for moves from a risky to a risky municipality, survey mode, cohort fixed effects, and year fixed effects are not shown. Robust standard errors are given in parentheses. Statistical significance at *** 1\%** 5\%*10\% level. 
Table A5. Effect of time since the move date on risk perception and avoidance behavior, by level of crime in current and previous place of residence, restrict sample to municipalities with $100+$ observations

\begin{tabular}{|c|c|c|c|c|c|c|}
\hline & \multicolumn{2}{|c|}{$\begin{array}{l}\text { "Bicycle theft is rare in } \\
\text { neighborhood" }\end{array}$} & \multicolumn{2}{|c|}{$\begin{array}{l}\text { "Burglary is rare in } \\
\text { neighborhood" }\end{array}$} & \multicolumn{2}{|c|}{$\begin{array}{l}\text { "Theft from car is rare in } \\
\text { neighborhood" }\end{array}$} \\
\hline & $\begin{array}{l}\text { Without } \\
\text { cohort FE } \\
(1)\end{array}$ & $\begin{array}{c}\text { With } \\
\text { cohort FE } \\
(2)\end{array}$ & $\begin{array}{l}\text { Without } \\
\text { cohort FE } \\
\text { (3) }\end{array}$ & $\begin{array}{c}\text { With } \\
\text { cohort FE } \\
(4)\end{array}$ & $\begin{array}{l}\text { Without } \\
\text { cohort FE } \\
\text { (5) }\end{array}$ & $\begin{array}{c}\text { With } \\
\text { cohort FE } \\
\text { (6) }\end{array}$ \\
\hline $\begin{array}{l}\text { Months since move } x \\
\text { move from safe to } \\
\text { safe neighborhood }\end{array}$ & $\begin{array}{l}-0.4167 * * * \\
(0.1319)\end{array}$ & $\begin{array}{l}-0.8160 * * * \\
(0.2128)\end{array}$ & $\begin{array}{l}-0.8358 * * * \\
(0.1149)\end{array}$ & $\begin{array}{l}-1.5130 * * * \\
(0.2001)\end{array}$ & $\begin{array}{l}-0.8560 * * * \\
(0.1139)\end{array}$ & $\begin{array}{l}-1.3573 * * * \\
(0.2006)\end{array}$ \\
\hline $\begin{array}{l}\text { Months since move } x \\
\text { move from risky to } \\
\text { safe neighborhood }\end{array}$ & $\begin{array}{l}-0.5628 * * * \\
(0.1200)\end{array}$ & $\begin{array}{l}-0.9638 * * * \\
(0.1987\end{array}$ & $\begin{array}{l}-0.8303 * * * \\
(0.1052)\end{array}$ & $\begin{array}{l}-1.5079 * * * \\
(0.1968)\end{array}$ & $\begin{array}{l}-0.9093 * * * \\
(0.1308)\end{array}$ & $\begin{array}{l}-1.4111 * * * \\
(0.2250)\end{array}$ \\
\hline $\begin{array}{l}\text { Months since move } x \\
\text { move from safe to } \\
\text { risky neighborhood }\end{array}$ & $\begin{array}{l}-0.3036 * * * \\
(0.1145)\end{array}$ & $\begin{array}{l}-0.7247 * * * \\
(0.1978)\end{array}$ & $\begin{array}{l}-0.6617 * * * \\
(0.1357)\end{array}$ & $\begin{array}{l}-1.3363 * * * \\
(0.2090)\end{array}$ & $\begin{array}{l}-0.7126 * * * \\
(0.1405)\end{array}$ & $\begin{array}{l}-1.2101 * * * \\
(0.2174)\end{array}$ \\
\hline $\begin{array}{l}\text { Months since move } x \\
\text { move from risky to } \\
\text { risky neighborhood }\end{array}$ & $\begin{array}{l}-0.3762 * * * \\
(0.0715)\end{array}$ & $\begin{array}{l}-0.7998 * * * \\
(0.1726)\end{array}$ & $\begin{array}{l}-0.5568 * * * \\
(0.0865)\end{array}$ & $\begin{array}{l}-1.2358 * * * \\
(0.1769)\end{array}$ & $\begin{array}{l}-0.6448 * * * \\
(0.0769)\end{array}$ & $\begin{array}{l}-1.1478 * * * \\
(0.1801)\end{array}$ \\
\hline$p$-value cohort-FE $=0$ & & 0.1209 & & 0.0029 & & 0.0365 \\
\hline $\begin{array}{l}\text { Number of } \\
\text { observations }\end{array}$ & 360,319 & 360,319 & 379,211 & 379,211 & 362,218 & 362,218 \\
\hline R-Squared & 0.023 & 0.023 & 0.044 & 0.044 & 0.025 & 0.025 \\
\hline
\end{tabular}

Notes. Results show coefficients for linear regression as in Equation (2). Coefficients are multiplied by a factor of 1,000. A neighborhood is denoted as safe if the crime rate is below average. A neighborhood is denoted as risky if the crime rate is above average. Coefficients for age, age squared, female, household size, education, labor force participation, home ownership, two or more moves during last 10 years, type of residence, for moves from a risky to a safe municipality, for moves from a safe to a risky municipality, for moves from a risky to a risky municipality, survey mode, cohort fixed effects, and fixed effects for neighborhood and year interactions are not shown. Robust standard errors (clustered at neighborhood level) are given in parentheses. Statistical significance at $* * * 1 \% * * 5 \%$ $* 10 \%$ level. 
Table A5. Effect of time since the move date on risk perception and avoidance behavior, by level of crime in current and previous place of residence, restrict sample to municipalities with $100+$ observations (continued)

\begin{tabular}{|c|c|c|c|c|c|c|}
\hline & \multicolumn{2}{|c|}{$\begin{array}{c}\text { "Violent crime is rare in } \\
\text { neighborhood" }\end{array}$} & \multicolumn{2}{|c|}{$\begin{array}{l}\text { "Frequently avoids } \\
\text { unsafe places in } \\
\text { neighborhood" }\end{array}$} & \multicolumn{2}{|c|}{$\begin{array}{l}\text { "Frequently doesn't allow } \\
\text { children to go to some } \\
\text { places in neighborhood" }\end{array}$} \\
\hline & $\begin{array}{l}\text { Without } \\
\text { cohort FE } \\
(7)\end{array}$ & $\begin{array}{c}\text { With } \\
\text { cohort FE } \\
(8)\end{array}$ & $\begin{array}{l}\text { Without } \\
\text { cohort FE } \\
\text { (9) }\end{array}$ & $\begin{array}{l}\text { With } \\
\text { cohort FE } \\
(10)\end{array}$ & $\begin{array}{l}\text { Without } \\
\text { cohort FE } \\
(11)\end{array}$ & $\begin{array}{c}\text { With } \\
\text { cohort FE } \\
(12)\end{array}$ \\
\hline $\begin{array}{l}\text { Months since move } x \\
\text { move from safe to } \\
\text { safe neighborhood }\end{array}$ & $\begin{array}{l}-0.4041 * * * \\
(0.0901)\end{array}$ & $\begin{array}{l}-1.1023^{* * *} \\
(0.1804)\end{array}$ & $\begin{array}{l}0.1835^{* * *} \\
(0.0521)\end{array}$ & $\begin{array}{l}0.4039 * * * \\
(0.1113)\end{array}$ & $\begin{array}{l}0.2776 * * * \\
(0.0997)\end{array}$ & $\begin{array}{l}0.7329 * * * \\
(0.1870)\end{array}$ \\
\hline $\begin{array}{l}\text { Months since move } x \\
\text { move from risky to } \\
\text { safe neighborhood }\end{array}$ & $\begin{array}{l}-0.3233 * * * \\
(0.1077)\end{array}$ & $\begin{array}{l}-1.0205^{* * *} \\
(0.1966)\end{array}$ & $\begin{array}{l}0.0752 \\
(0.0497)\end{array}$ & $\begin{array}{l}0.2960 * * * \\
(0.1103\end{array}$ & $\begin{array}{l}0.2651 * * * \\
(0.0951)\end{array}$ & $\begin{array}{l}0.7204 * * * \\
(0.1901)\end{array}$ \\
\hline $\begin{array}{l}\text { Months since move } x \\
\text { move from safe to } \\
\text { risky neighborhood }\end{array}$ & $\begin{array}{l}-0.5558 * * * \\
(0.1369)\end{array}$ & $\begin{array}{l}-1.2333^{* * *} \\
(0.2081)\end{array}$ & $\begin{array}{l}0.1072 \\
(0.0712)\end{array}$ & $\begin{array}{l}0.3240 * * * \\
(0.1134)\end{array}$ & $\begin{array}{l}0.5112 * * * \\
(0.1524)\end{array}$ & $\begin{array}{l}0.9536 * * * \\
(0.2216)\end{array}$ \\
\hline $\begin{array}{l}\text { Months since move } x \\
\text { move from risky to } \\
\text { risky neighborhood }\end{array}$ & $\begin{array}{l}-0.4827 * * * \\
(0.0811)\end{array}$ & $\begin{array}{l}-1.1648 * * * \\
(0.1670)\end{array}$ & $\begin{array}{l}-0.0024 \\
(0.0473)\end{array}$ & $\begin{array}{l}0.2153^{* *} \\
(0.1038)\end{array}$ & $\begin{array}{l}0.2090 * * \\
(0.0939)\end{array}$ & $\begin{array}{l}0.6532 * * * \\
(0.1764)\end{array}$ \\
\hline$p$-value cohort-FE $=0$ & & 0.0086 & & 0.1084 & & 0.0426 \\
\hline $\begin{array}{l}\text { Number of } \\
\text { observations }\end{array}$ & 346,040 & 346,040 & 327,533 & 327,533 & 161,156 & 161,156 \\
\hline R-Squared & 0.023 & 0.023 & 0.018 & 0.018 & 0.019 & 0.019 \\
\hline
\end{tabular}

Notes. Results show coefficients for linear regression as in Equation (2). Coefficients are multiplied by a factor of 1,000. A neighborhood is denoted as safe if the crime rate is below average. A neighborhood is denoted as risky if the crime rate is above average. Coefficients for age, age squared, female, household size, education, labor force participation, home ownership, two or more moves during last 10 years, type of residence, for moves from a risky to a safe municipality, for moves from a safe to a risky municipality, for moves from a risky to a risky municipality, survey mode, cohort fixed effects, and fixed effects for neighborhood and year interactions are not shown. Robust standard errors (clustered at neighborhood level) are given in parentheses. Statistical significance at $* * * 1 \% * * 5 \%$ * $10 \%$ level. 